\title{
Solubility and solid phase of trivalent lanthanide hydroxides and oxides
}

\author{
Md. Moniruzzaman ${ }^{1, *}$, Taishi Kobayashi',*, Takayuki Sasaki \\ Department of Nuclear Engineering, Kyoto University, Kyotodaigaku-katsura, Nishikyo-ku, Kyoto 615-8540, \\ Japan
}

Received March 10, 2020; Accepted June 10, 2020; Published online June 26, 2020

\begin{abstract}
An undersaturation approach was adopted to reveal the solubility and solubility-limiting solid phase of La, Eu and Tm in the sample solutions with the ionic strength $(I)$ of $0.1 \mathrm{~mol} / \mathrm{L}(\mathrm{M})$ and the hydrogen ion concentration range $\left(\mathrm{pH}_{\mathrm{c}}=-\log \left[\mathrm{H}^{+}\right]\right)$of 6 to 12 after aging at 25 to $90^{\circ} \mathrm{C}$ for certain periods up to 12 weeks. Solubility and solubilitylimiting solid phases were discussed with the aid of X-ray diffraction (XRD) patterns of the solid phases and temperature dependence of solubility products $\left(\log K_{\mathrm{s}}^{\circ}\right)$ values. The XRD patterns of the solid phases indicated that the initial solid phase of $\mathrm{La}_{2} \mathrm{O}_{3}(\mathrm{cr})$ transformed to $\mathrm{La}(\mathrm{OH})_{3}(\mathrm{cr})$ after aging at $25^{\circ} \mathrm{C}$ and $90{ }^{\circ} \mathrm{C}$. On the other hand, $\mathrm{Eu}_{2} \mathrm{O}_{3}(\mathrm{cr})$ remained stable after aging at $25{ }^{\circ} \mathrm{C}$, but after $90{ }^{\circ} \mathrm{C}$, converted to $\mathrm{Eu}(\mathrm{OH})_{3}(\mathrm{cr})$. It was observed that $\mathrm{Tm}_{2} \mathrm{O}_{3}$ (cr) was not transformed after aging at both $25^{\circ} \mathrm{C}$ or $90^{\circ} \mathrm{C}$. Thermodynamic properties obtained from the temperature dependence of the solubility products agreed well with the observations in the XRD patterns.
\end{abstract}

\section{Introduction}

For the safety assessment of radioactive waste disposal, it is necessary to predict the migration behavior of actinide elements under relevant geochemical conditions, as they are included in the waste as alpha-emitting radionuclides with long half-lives. Actinide elements of thorium, uranium, neptunium, and plutonium can exist in a tetravalent oxidation state under reducing geochemical conditions, deep underground and easily precipitate as a sparingly soluble amorphous hydroxide solid phase $\left(\mathrm{An}(\mathrm{IV})(\mathrm{OH})_{4}(\mathrm{am})\right)$ under neutral to alkaline $\mathrm{pH}$ conditions of the waste repository systems [1-4]. The solubilities of $\mathrm{An}(\mathrm{IV})(\mathrm{OH})_{4}(\mathrm{am})$, hence, play an important role in understanding their migration behavior. It is known that a crystalline oxide solid phase as $\mathrm{An}(\mathrm{IV}) \mathrm{O}_{2}(\mathrm{cr})$ is thermodynamically more stable and it has been reported that the crystallization of $\mathrm{An}(\mathrm{IV})(\mathrm{OH})_{4}(\mathrm{am})$ towards $\mathrm{An}(\mathrm{IV}) \mathrm{O}_{2}(\mathrm{cr})$ proceeded under certain solution conditions such as strong alkaline $\mathrm{pH}$ or elevated temperatures [5-7]. The solubilities of $\mathrm{An}(\mathrm{IV}) \mathrm{O}_{2}$ (cr) have been reported to several orders of magnitude lower than those of $\mathrm{An}(\mathrm{IV})(\mathrm{OH})_{4}(\mathrm{am})$ [1-7].

Trivalent actinide elements of americium and curium also exhibit a strong hydrolysis reactions under neutral to alkaline $\mathrm{pH}$ conditions to precipitate the sparingly soluble amorphous hydroxide solid phase $\left(\mathrm{An}(\mathrm{III})(\mathrm{OH})_{3}(\mathrm{am})\right)$ [8-11]. In contrast to the tetravalent actinide elements, no crystalline oxide solid phase $\left(\mathrm{An}(\mathrm{III})_{2} \mathrm{O}_{3}(\mathrm{cr})\right)$ was observed in the solubility experiments $[2,12]$. A few literatures have observed crystalline hydroxide solid phase $\left(\mathrm{An}(\mathrm{III})(\mathrm{OH})_{3}(\mathrm{cr})\right)$ from X-ray diffraction patterns instead of $\mathrm{An}(\mathrm{III})_{2} \mathrm{O}_{3}$ (cr) and showed an order of magnitude lower solubility values than those of An(III) $(\mathrm{OH})_{3}(\mathrm{am})[13,14]$. This can be explained by thermodynamic data of $\mathrm{An}(\mathrm{III})_{2} \mathrm{O}_{3}(\mathrm{cr})$. For example, the standard enthalpy $\left(\Delta_{\mathrm{f}} H_{\mathrm{m}}^{\circ}\right)$ and entropy $\left(S_{\mathrm{m}}^{\circ}\right)$ of $\mathrm{Am}_{2} \mathrm{O}_{3}(\mathrm{cr})$ have been reported to be $\Delta_{\mathrm{f}} H_{\mathrm{m}}^{\circ}=-1690.4 \pm 8.0 \mathrm{~kJ} / \mathrm{mol}$ and $S_{\mathrm{m}}^{\circ}=133.6 \pm 6.0 \mathrm{~J} / \mathrm{K} / \mathrm{mol}$ resulted in the standard formation Gibbs energy of $\Delta_{\mathrm{f}} G_{\mathrm{m}}^{\circ}=$ $-1605.449 \pm 8.284$ [2]. Combined with the thermodynamic data for $\mathrm{Am}^{3+}$ and $\mathrm{H}_{2} \mathrm{O}$ [2], the standard reaction Gibbs energy $\left(\Delta_{\mathrm{r}} G_{\mathrm{m}}^{\circ}\right)$ for $1 / 2 \mathrm{Am}_{2} \mathrm{O}_{3}(\mathrm{cr})+3 \mathrm{H}^{+} \rightleftharpoons \mathrm{Am}^{3+}+3 / 2 \mathrm{H}_{2} \mathrm{O}$ was calculated to be $\Delta_{\mathrm{r}} G_{\mathrm{m}}^{\circ}=-151.59 \mathrm{~kJ} / \mathrm{mol}$, leading to the solubility

*Corresponding author. Email: ${ }^{1}$ mohammad.moniruzzaman.23c@ st.kyoto-u.ac.jp, ${ }^{2}$ kobayashi@nucleng.kyoto-u.ac.jp product $\left(K_{\mathrm{s}}^{\circ}\right)$ of $\log K_{\mathrm{s}}^{\circ}=26.56$. This value is approximately 10 orders of magnitude higher than those reported for $\mathrm{Am}(\mathrm{OH})_{3}(\mathrm{am})$ and $\mathrm{Am}(\mathrm{OH})_{3}(\mathrm{cr})[2,4]$, hinting the oxide solid phase is less stable in aqueous systems. However, due to experimental limitations for handling macro amounts of trivalent actinide elements, only few studies have investigated the An(III) solubility with a definite solid phase characterization $[8,11,13]$ and the stability of $\mathrm{An}(\mathrm{III})_{2} \mathrm{O}_{3}$ (cr) in aqueous systems has not been well experimentally clarified.

Trivalent lanthanide elements are often used as analogues of trivalent actinide elements. A number of literatures have investigated the hydrolysis behavior, solubilities and solid phases of lighter to heavier lanthanide elements and reported their thermodynamic data [15-24]. Several works occasionally summarized the state of knowledge on the solubilities of trivalent lanthanide elements [25-28]. Most recently, Brown and Ekberg [4] have compiled the literature data on the hydrolysis of lanthanide elements and selected the recommended values for the solubility product of hydroxide solid phase ( $\mathrm{Ln}$ (III) $\left.(\mathrm{OH})_{3}(\mathrm{~s})\right)$ and related thermodynamic data. It is noted that the solubility product of amorphous hydroxide solid phase (Ln(III) $(\mathrm{OH})_{3}(\mathrm{am})$ ) obtained after short aging periods was excluded in the review due to poor identification of the solid phase [4]. Konings et al. [29] conducted a comprehensive review on the thermodynamic properties of lanthanide and actinide oxides, where recommended values of $\Delta_{\mathrm{f}} H_{\mathrm{m}}^{\circ}$ and $S_{\mathrm{m}}^{\circ}$ for the lanthanide oxide solid phase $\left(\mathrm{Ln}(\mathrm{III})_{2} \mathrm{O}_{3}(\mathrm{cr})\right)$ were selected. For example, the values of $\Delta_{\mathrm{f}} H_{\mathrm{m}}^{\circ}$ and $S_{\mathrm{m}}^{\circ}$ for $\mathrm{La}_{2} \mathrm{O}_{3}$ (cr) were selected to be $\Delta_{\mathrm{f}} H_{\mathrm{m}}^{\circ}=-1791.6 \pm 2.0 \mathrm{~kJ} / \mathrm{mol}$ and $S_{\mathrm{m}}^{\circ}=127.32 \pm 0.84 \mathrm{~J} / \mathrm{K} / \mathrm{mol}$, based on the reported results by solution calorimetry and heat capacity measurements [29]. The calculated $\Delta_{\mathrm{f}} G_{\mathrm{m}}^{\circ}$ and subsequently $\Delta_{\mathrm{r}} G_{\mathrm{m}}^{\circ}$ for $1 / 2 \mathrm{La}_{2} \mathrm{O}_{3}(\mathrm{cr})+3 \mathrm{H}^{+} \rightleftharpoons \mathrm{La}^{3+}+3 / 2 \mathrm{H}_{2} \mathrm{O}$ was $-192.33 \mathrm{~kJ} / \mathrm{mol}$, leading to $\log K_{\mathrm{s}}^{\circ}=33.70$, which is much larger than the selected $K_{\mathrm{s}}^{\circ}$ value for $\mathrm{La}(\mathrm{OH})_{3}(\mathrm{~s})\left(\log K_{\mathrm{s}}^{\circ}=\right.$ 19.72) [4]. The transformation of $\mathrm{Ln}(\mathrm{III})_{2} \mathrm{O}_{3}$ (cr) to $\mathrm{Ln}(\mathrm{III})$ $(\mathrm{OH})_{3}(\mathrm{cr})$ in aqueous systems was observed in a few literatures [30-32]. The formation of $\mathrm{Ln}(\mathrm{III})(\mathrm{OH})_{3}(\mathrm{cr})$ was observed by precipitating $\mathrm{Ln}(\mathrm{III})$ solutions with $\mathrm{NaOH}$, after complete dissolution of initial $\mathrm{Ln}(\mathrm{III})_{2} \mathrm{O}_{3}$ (cr) with a hot nitrate solution [31]. Neck et al. [32] observed that the initial material of $\mathrm{Nd}_{2} \mathrm{O}_{3}(\mathrm{cr})$ was converted to $\mathrm{Nd}(\mathrm{OH})_{3}(\mathrm{cr})$ in a purified water at $25^{\circ} \mathrm{C}$ after a few months, prior to the their solubility experiment of 
$\mathrm{Nd}(\mathrm{OH})_{3}(\mathrm{cr})$. However, not many literatures have investigated the solid phase transformation from lighter to heavier lanthanide elements with a combination of definite solid phase characterization and solubility measurement. It is evident that, clarifying the "solubility-limiting solid phase" is essential for the reliable prediction of the solubility limits of trivalent radionuclides.

The present study focuses on the solubilities and solid phases of trivalent lanthanum $(\mathrm{La})$, europium $(\mathrm{Eu})$ and thulium (Tm), in neutral to alkaline $\mathrm{pH}$ range to clarify the "solubilitylimiting solid phase." The solubility experiments were conducted with an undersaturation approach by adding the solid phases of crystalline oxides $\left(\mathrm{La}_{2} \mathrm{O}_{3}(\mathrm{cr}), \mathrm{Eu}_{2} \mathrm{O}_{3}(\mathrm{cr})\right.$, and $\mathrm{Tm}_{2} \mathrm{O}_{3}(\mathrm{cr})$ ) into sample solutions, at given hydrogen ion concentration $\left(\mathrm{pH}_{\mathrm{c}}=-\log \left[\mathrm{H}^{+}\right]\right)$and ionic strength $(I=0.1 \mathrm{~mol} / \mathrm{L}$ (M) by $\left.\mathrm{NaClO}_{4}\right)$ ). The sample solutions were then aged under temperature conditions of $T_{\text {age }}=25,40,50,60$, and $90^{\circ} \mathrm{C}$, for certain periods up to 12 weeks. After aging at 25 to $90^{\circ} \mathrm{C}$, the sample solutions were set down at a certain measurement temperature $\left(T_{\text {meas }}\right)$ of $25,40,50$, and $60^{\circ} \mathrm{C}$ for the solubility measurement. The solubilities of $\mathrm{La}, \mathrm{Eu}$, and Tm were measured, and their solid phases were investigated by X-ray diffraction (XRD). The solubility-limiting solid phase for $\mathrm{La}, \mathrm{Eu}$, and $\mathrm{Tm}$ was discussed alongside the XRD patterns of the solid phases and the temperature dependence of the solubility products.

\section{Experimental}

2.1. Materials and sample preparation. Reagent grades of sodium perchlorate monohydrate $\left(\mathrm{NaClO}_{4} \cdot \mathrm{H}_{2} \mathrm{O}, 98 \%\right)$, perchloric acid $\left(\mathrm{HClO}_{4}, 60 \%\right)$, sodium hydroxide $(\mathrm{NaOH}, 97 \%)$, were purchased from WAKO Pure Chem. HEPES $\left(\mathrm{C}_{8} \mathrm{H}_{18} \mathrm{~N}_{2} \mathrm{O}_{4} \mathrm{~S}, 99.0 \%\right.$, Dojindo) was used to adjust $\mathrm{pH}$ of sample solutions to the neutral $\mathrm{pH}$ region. Lanthanum oxide $\left(\mathrm{La}_{2} \mathrm{O}_{3}\right.$, $99.99 \%$ ), europium oxide $\left(\mathrm{Eu}_{2} \mathrm{O}_{3}, 99.9 \%\right)$, and thulium oxide $\left(\mathrm{Tm}_{2} \mathrm{O}_{3}, 99.9 \%\right)$ were also purchased from WAKO Pure Chem., and were used without any prior treatments. The appearance of these initial oxides was investigated using a desktop scanning electron microscope (JCM-6000 NeoScope, JEOL) and the particles size of these oxides were found to be 1-3 $\mu \mathrm{m}$. Deionized purified water (Milli-Q, Millipore) was used in the preparation of all solutions. The sample preparation was conducted in a $\mathrm{CO}_{2}$ free, argon gas filled glove box, at $25{ }^{\circ} \mathrm{C}$ and $1 \mathrm{~atm}$ to prevent entering $\mathrm{CO}_{2}$ in the sample solutions. The $\mathrm{pH}_{\mathrm{c}}$ values of the samples were measured by a $\mathrm{pH}$ meter (D-72, Horiba Ltd.) with a combined glass electrode (9615-10D, Horiba Ltd.). The reference electrode was filled with $3.89 \mathrm{M} \mathrm{NaCl}$ and $0.41 \mathrm{M} \mathrm{NaClO}_{4}$ (Wako Pure Chem.). The electrode was calibrated against standard $\mathrm{HClO}_{4}$ and $\mathrm{NaOH}$ solutions $\left(\mathrm{pH}_{\mathrm{c}} 1,2,3,11,12\right.$, and 13; Wako Pure Chem.) at $I=0.1 \mathrm{M}$ using $\mathrm{NaClO}_{4}$ at $25,40,50$, and $60{ }^{\circ} \mathrm{C}$ to correct the experimentally measured $\mathrm{pH}_{\exp }$ values, to the $\mathrm{pH}_{\mathrm{c}}$ values at different temperatures.

Sample solutions were prepared by an undersaturation approach. A certain amount of $0.1 \mathrm{M} \mathrm{NaClO}_{4}$ solution was prepared as an initial solution. Then, $0.1 \mathrm{M} \mathrm{HClO}_{4}$ or $0.1 \mathrm{M}$ $\mathrm{NaOH}$ was added to the initial solution to adjust the $\mathrm{pH}_{\mathrm{c}}$, so that the ionic strength $(I)$ of the initial solution kept constant at $I=0.1 \mathrm{M}$. Each $10 \mathrm{~mL}$ of aliquot was withdrawn at fixed $\mathrm{pH}$ levels ranging from $\mathrm{pH}_{\mathrm{c}} 7$ to 12 and put into polypropylene tubes. For the sample solutions in the neutral $\mathrm{pH}$ region, an appropriate amount of $0.1 \mathrm{M}$ HEPES solution was added to stabilize the $\mathrm{pH}_{\mathrm{c}}$. The concentration of HEPES was $10^{-3} \mathrm{M}$ for each sample solution. The La stock suspension was prepared by adding $16.3 \mathrm{~g}$ of $\mathrm{La}_{2} \mathrm{O}_{3}$ in $50 \mathrm{~mL}$ of pure water. If the $\mathrm{La}_{2} \mathrm{O}_{3}$ solid phase totally dissolved, the concentration would correspond to $2.0 \mathrm{M}$. An aliquot of $50 \mu \mathrm{L}$ stock suspension was then added to each $10 \mathrm{~mL}$ of sample solution, so that the $\mathrm{La}$ concentration of the sample solution would be $0.01 \mathrm{M}$, if the added solid phase completely dissolved. The Eu and Tm stock suspensions were prepared by adding $17.6 \mathrm{~g}$ and $19.3 \mathrm{~g}$ of $\mathrm{Eu}_{2} \mathrm{O}_{3}$ and $\mathrm{Tm}_{2} \mathrm{O}_{3}$, respectively in $50 \mathrm{~mL}$ of pure waters and the sample solutions containing $\mathrm{Eu}_{2} \mathrm{O}_{3}$ and $\mathrm{Tm}_{2} \mathrm{O}_{3}$ were prepared in the same method as those of $\mathrm{La}_{2} \mathrm{O}_{3}$. For the solid phase analysis, aliquots of $10 \mathrm{~mL}$ of the La stock suspension, containing approximately $3.3 \mathrm{~g}$ of $\mathrm{La}_{2} \mathrm{O}_{3}$, was added in $100 \mathrm{~mL}$ of sample solutions. The La concentration would be $0.2 \mathrm{M}$ if the added solid phase completely dissolved. Similarly, $100 \mathrm{~mL}$ of sample solutions containing $3.5 \mathrm{~g}$ of $\mathrm{Eu}_{2} \mathrm{O}_{3}$ and $3.8 \mathrm{~g}$ of $\mathrm{Tm}_{2} \mathrm{O}_{3}$ at certain $\mathrm{pH}$ conditions were prepared for the solid phase analysis. After the preparation, caps of the sample tubes were tightly closed, and the tubes were taken from the Ar glove box. The sample tubes were placed and stored in temperature chambers controlled at the aging temperatures $\left(T_{\text {age }}\right)$ at $25,40,50,60$, and $90{ }^{\circ} \mathrm{C}$ for up to 12 weeks (TAITEC BIOShaker BR-43F2 for $25^{\circ} \mathrm{C}$ and ETTAS E0450B for 40 to $\left.90{ }^{\circ} \mathrm{C}\right)$. The sample tubes were shaken by a shaker equipped with the temperature chamber during the aging at $25^{\circ} \mathrm{C}$, and shaken by hand occasionally for a few minutes during the aging at 40 to $90{ }^{\circ} \mathrm{C}$.

2.2. Solid phase analysis. After aging at 25 and $90{ }^{\circ} \mathrm{C}$ for given periods, selected sample tubes were taken from the temperature cambers and kept at room temperature for 1 day. The $\mathrm{pH}_{\mathrm{c}}$ of the sample solution was measured and the solid phase was separated by centrifuging at 5,000 rpm (H-103N, Kokusan) for 5 min under atmospheric conditions, and dried in a vacuum desiccator for several hours. The diffraction patterns of the solid phase were then collected using XRD (Miniflex, RIGAKU), with $\mathrm{Cu}-\mathrm{K} \alpha(\lambda=0.154 \mathrm{~nm})$ in the range of scattering angle $2 \theta=10$ to $60^{\circ}$, and a scan rate of $20 \% \mathrm{~min}$. The solid phase samples of $\mathrm{La}_{2} \mathrm{O}_{3}, \mathrm{Eu}_{2} \mathrm{O}_{3}$, and $\mathrm{Tm}_{2} \mathrm{O}_{3}$ prior to adding into the sample solutions were measured as references and compared to those after aging at 25 and $90{ }^{\circ} \mathrm{C}$.

2.3. Solubility measurement. After aging the sample solutions at $25,40,50,60$, and $90{ }^{\circ} \mathrm{C}$ for certain weeks, the sample tubes were taken out from the temperature chambers. Then, the sample tubes were placed in thermostatted baths maintained at the measurement temperature $\left(T_{\text {meas }}\right)$ of $T_{\text {meas }}=25,40$, 50 , and $60{ }^{\circ} \mathrm{C}$, as described elsewhere [33,34]. The studied conditions were summarized in Table 1. After 1 day under respective $T_{\text {meas }}$ conditions, the $\mathrm{pH}$ measurements and ultrafiltrations of the sample solutions at the desired temperatures were performed. The observed $\mathrm{pH}$ values at each $T_{\text {meas }}$ were corrected to their $\mathrm{pH}_{\mathrm{c}}$ values using temperature-specific calibration curves. The $0.5 \mathrm{~mL}$ of supernatants of the sample solutions were filtrated through ultrafiltration membranes (Microcon, nominal molecular weight limit (NMWL) of 3,000 $(3 \mathrm{kDa})$, corresponding to pore sizes of approximately $2 \mathrm{~nm}$, Millipore). Filter units and membranes were equilibrated at each $T_{\text {meas }}$ prior to the ultrafiltration, and the $T_{\text {meas }}$ values during the ultrafiltration were maintained by the thermostat equipped with the centrifuge device (CF15R, Hitachi Koki Co. Ltd.) run at 13,000 rpm for 20 minutes in the case of $T_{\text {meas }}=25$ or $40{ }^{\circ} \mathrm{C}$. A desktop centrifuge (FB-4000, Kurabo) introduced in a temperature chamber was used to filtrate the sample solutions at $T_{\text {meas }}$ in the case of $T_{\text {meas }}=50$ and $60{ }^{\circ} \mathrm{C}$. After the $\mathrm{pH}$ measurement and ultrafiltration at each $T_{\text {meas }}$, the sample solutions were returned to the temperature chambers. A few of the sample tubes were kept at $T_{\text {meas }}$ longer than 1 day and $\mathrm{pH}$ measurement and ultrafiltration at the $T_{\text {meas }}$ were repeated to confirm the steady state was achieved at the $T_{\text {meas }}$. The whole solubility measurements were repeated several times for different aging times up to 12 weeks. After the ultrafiltration at each $T_{\text {meas }}, 0.3 \mathrm{~mL}$ of filtrate was taken and acidified with 2.0 $\mathrm{mL}$ of $0.1 \mathrm{M} \mathrm{HNO}_{3}$. The $\mathrm{La}, \mathrm{Eu}$, and Tm concentrations were then measured by ICP-MS (ELANDRC II, PerkinElmer). The 
detection limit was approximately $10^{-9} \mathrm{M}$ for each element. The solubility measurement was repeated several times, to confirm if the solubility reaction reached the steady state. The standard error was within $10 \%$ for each measurement by ICP-MS, which resulted in \pm 0.1 in the $\log$ unit of $\mathrm{La}, \mathrm{Eu}$, and Tm concentrations. It is note that taking three different supernatants from a certain sample tube resulted in a maximum scattering of $\log [\mathrm{Ln}]= \pm 0.5$.

\section{Results and discussion}

\subsection{Solid phases after aging at 25 and $90{ }^{\circ} \mathrm{C}$}

3.1.1. La solid phases after aging at 25 and $90^{\circ} \mathrm{C}$. Figure 1 shows the XRD patterns for La solid phases after aging of the sample solutions at 25 and $90{ }^{\circ} \mathrm{C}$, in the neutral to alkaline $\mathrm{pH}$ region for 4 weeks. The XRD pattern of $\mathrm{La}_{2} \mathrm{O}_{3}(\mathrm{cr})$ was measured at its initial state and shown in Fig. 1 for comparison. After aging the sample solutions under the above mentioned conditions, the XRD patterns showed that, the peaks corresponding to the initial $\mathrm{La}_{2} \mathrm{O}_{3}$ (cr) showing the hexagonal antiprismatic structure disappeared, whereas those corresponding to $\mathrm{La}(\mathrm{OH})_{3}(\mathrm{cr})$ as the $\mathrm{UCl}_{3}$-type structure (trigonal prismatic) (ICSD No. 31584) appeared. This indicates that the initial $\mathrm{La}_{2} \mathrm{O}_{3}(\mathrm{~s})$ transformed to $\mathrm{La}(\mathrm{OH})_{3}(\mathrm{cr})$, by aging of the sample solutions at 25 and $90{ }^{\circ} \mathrm{C}$ for 4 weeks. It was in fact noted from the XRD patterns, that the transformation of $\mathrm{La}_{2} \mathrm{O}_{3}(\mathrm{cr})$ to $\mathrm{La}(\mathrm{OH})_{3}(\mathrm{cr})$ already took place after aging at 25 and $90{ }^{\circ} \mathrm{C}$ for 1 week, suggesting that the solid phase transformation has rather fast kinetics under the investigative experimental conditions. This confirms that the solid phase of $\mathrm{La}_{2} \mathrm{O}_{3}(\mathrm{cr})$ is unstable and it transforms to $\mathrm{La}(\mathrm{OH})_{3}(\mathrm{cr})$ in aqueous solutions, as has been pointed out in previous literature, where $\mathrm{La}_{2} \mathrm{O}_{3}(\mathrm{cr})$ was dissolved in a heated nitrate solution [31]. Similar transformation was observed for $\mathrm{Nd}_{2} \mathrm{O}_{3}$ (cr), where $\mathrm{Nd}_{2} \mathrm{O}_{3}$ (cr) converted to $\mathrm{Nd}(\mathrm{OH})_{3}(\mathrm{cr})$ after aging in pure water at $25{ }^{\circ} \mathrm{C}$ for 3 months [32]. It can also be observed from Fig. 1, that there is no significant difference between the XRD patterns of the solid phases, aged at different $\mathrm{pH}_{\mathrm{c}}$ conditions and aging temperatures.

3.1.2. Eu solid phases after aging at 25 and $90^{\circ} \mathrm{C}$. In Fig. 2 , the XRD patterns of Eu solid phases, derived after aging of the sample solutions at 25 and $90{ }^{\circ} \mathrm{C}$ in neutral to alkaline $\mathrm{pH}$ region for 4 weeks, were compared with those of the initial state of $\mathrm{Eu}_{2} \mathrm{O}_{3}$ (cr) which exhibited cubic structure (ICSD No.27997). After aging at $25^{\circ} \mathrm{C}$, the XRD patterns corresponded to that of the initial $\mathrm{Eu}_{2} \mathrm{O}_{3}(\mathrm{cr})$ solid phase, indicating that no phase transformation occurred at $25^{\circ} \mathrm{C}$. On the other hand, after aging at $90^{\circ} \mathrm{C}$, the peak positions of the samples changed, and were identified as those of $\mathrm{Eu}(\mathrm{OH})_{3}(\mathrm{cr})$, that had $\mathrm{UCl}_{3}$-type structure (ICSD No. 200488). This suggests that $\mathrm{Eu}_{2} \mathrm{O}_{3}$ (cr) transformed to $\mathrm{Eu}(\mathrm{OH})_{3}(\mathrm{cr})$ during the aging at $90{ }^{\circ} \mathrm{C}$, whereas no solid phase transformation occurred at $25^{\circ} \mathrm{C}$. It is further noted, that the solid phase transformation from $\mathrm{Eu}_{2} \mathrm{O}_{3}$ (cr) to $\mathrm{Eu}(\mathrm{OH})_{3}(\mathrm{cr})$ at $90{ }^{\circ} \mathrm{C}$ in fact occurs after aging for just 1 week. This difference in trend between the solid phase transformations for $\mathrm{Eu}_{2} \mathrm{O}_{3}(\mathrm{cr})$ and $\mathrm{La}_{2} \mathrm{O}_{3}(\mathrm{cr}), \mathrm{Nd}_{2} \mathrm{O}_{3}(\mathrm{cr})$, may be related to the difference in their crystal structures; $\mathrm{La}_{2} \mathrm{O}_{3}(\mathrm{cr})$ and $\mathrm{Nd}_{2} \mathrm{O}_{3}$ (cr) have the hexagonal phase, whereas $\mathrm{Eu}_{2} \mathrm{O}_{3}(\mathrm{cr})$ has the cubic phase.

3.1.3. Tm solid phases after aging at 25 and $90^{\circ} \mathrm{C}$. In Fig. 3, the XRD patterns of Tm solid phases, after aging at 25 and $90{ }^{\circ} \mathrm{C}$ in the neutral to alkaline $\mathrm{pH}_{\mathrm{c}}$ region for 4 weeks, were presented together with that of the initial $\mathrm{Tm}_{2} \mathrm{O}_{3}(\mathrm{cr})$ solid phase exhibiting cubic structure. The XRD patterns did not change after aging at both temperatures and remained stable as the initial $\mathrm{Tm}_{2} \mathrm{O}_{3}$ (cr) (ICSD No. 33657). The same peak patterns were obtained for samples aged at $25^{\circ} \mathrm{C}$ and $90{ }^{\circ} \mathrm{C}$ for 1 week.

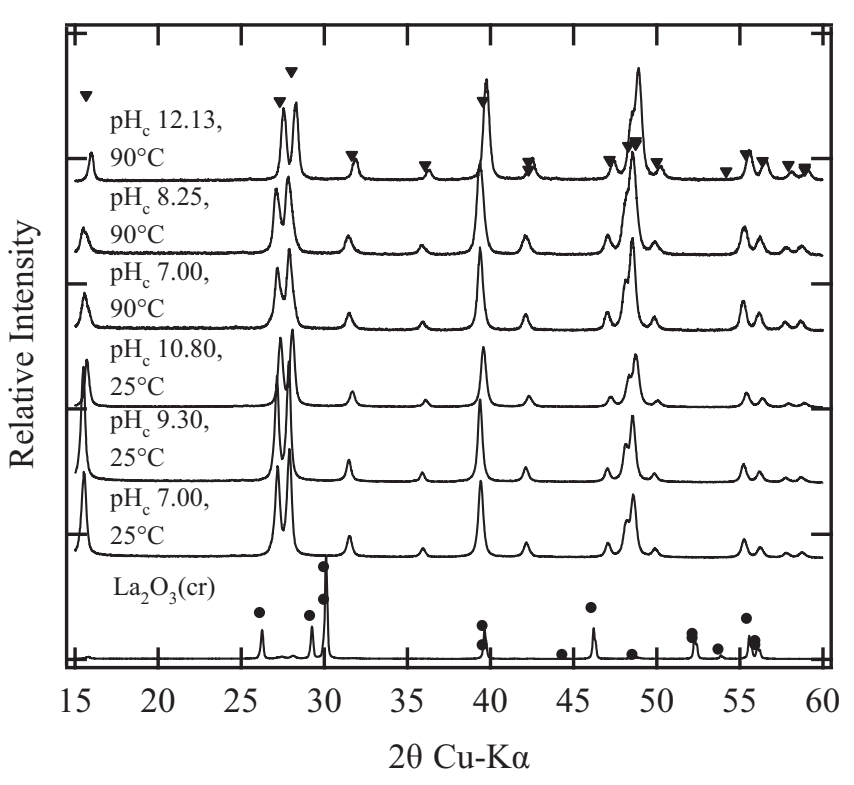

Figure 1. XRD patterns of the La solid phases after aging for 4 weeks at $\mathrm{pH}_{\mathrm{c}} 7.00,9.30$, and 10.80 at $25^{\circ} \mathrm{C}$ and at $\mathrm{pH}_{\mathrm{c}} 7.00,8.25$, and 12.13 at $90{ }^{\circ} \mathrm{C}$, together with that of $\mathrm{La}_{2} \mathrm{O}_{3}(\mathrm{cr})$ as the initial solid phase. Filled circles $(\bullet)$ and triangles $(\boldsymbol{\nabla})$ represent the peaks from ICSD patterns of $\mathrm{La}_{2} \mathrm{O}_{3}$ (No. 10278) and $\mathrm{La}(\mathrm{OH})_{3}$ (No. 31584), respectively.

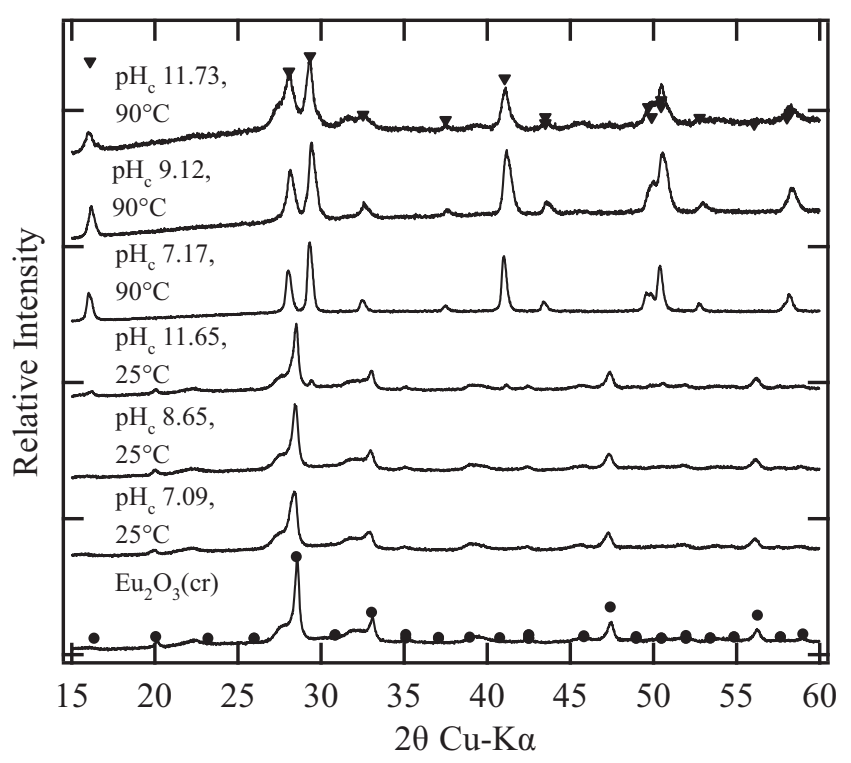

Figure 2. XRD patterns of the Eu solid phases after aging for 4 weeks at $\mathrm{pH}_{\mathrm{c}} 7.09,8.65$ and 11.65 at $25^{\circ} \mathrm{C}$ and at $\mathrm{pH}_{\mathrm{c}} 7.17,9.12$, and 11.73 at $90{ }^{\circ} \mathrm{C}$, together with that of $\mathrm{Eu}_{2} \mathrm{O}_{3}(\mathrm{cr})$ as the initial solid phase. Filled circles $(\bullet)$ and triangles $(\boldsymbol{\nabla})$ represent the peaks from ICSD patterns of $\mathrm{Eu}_{2} \mathrm{O}_{3}$ (No. 27997) and $\mathrm{Eu}(\mathrm{OH})_{3}$ (No. 200488), respectively.

The results of the solid phase analysis are summarized in Table 1, together with the aging temperature conditions.

\subsection{Solubilities measured at $25^{\circ} \mathrm{C}$ after aging at 25 to $90{ }^{\circ} \mathrm{C}$}

3.2.1. La Solubilities measured at $25^{\circ} \mathrm{C}$ after aging at 25 to $90^{\circ} \mathrm{C}$. The XRD patterns of the La solid phase indicated that the initial $\mathrm{La}_{2} \mathrm{O}_{3}(\mathrm{cr})$ converted to $\mathrm{La}(\mathrm{OH})_{3}(\mathrm{cr})$ after aging of its sample solutions, at 25 and $90{ }^{\circ} \mathrm{C}$ for more than 1 week. As described above, the reported values of $\Delta_{\mathrm{f}} H_{\mathrm{m}}^{\circ}=-1791.6 \pm 2.0$ $\mathrm{kJ} / \mathrm{mol}$ and $S_{\mathrm{m}}^{\circ}=127.32 \pm 0.84 \mathrm{~J} / \mathrm{K} / \mathrm{mol}$ for $\mathrm{La}_{2} \mathrm{O}_{3}$ (cr) [29] resulted in $\Delta_{\mathrm{r}} G_{\mathrm{m}}^{\circ}=-192.33 \mathrm{~kJ} / \mathrm{mol}$, and $\log K_{\mathrm{s}}^{\circ}=33.70$ at $25^{\circ} \mathrm{C}$ for $1 / 2 \mathrm{La}_{2} \mathrm{O}_{3}(\mathrm{cr})+3 \mathrm{H}^{+} \rightleftharpoons \mathrm{La}^{3+}+3 / 2 \mathrm{H}_{2} \mathrm{O}$ combined with the $\Delta_{\mathrm{f}} H_{\mathrm{m}}^{\circ}$ and $S_{\mathrm{m}}^{\circ}$ for $\mathrm{La}^{3+}$ and $\mathrm{H}_{2} \mathrm{O}[2,4]$. Larger $\log K_{\mathrm{s}}^{\circ}$ value for $\mathrm{La}_{2} \mathrm{O}_{3}$ (cr) possibly leads the transformation of initial $\mathrm{La}_{2} \mathrm{O}_{3}$ (cr) 
to $\mathrm{La}(\mathrm{OH})_{3}(\mathrm{cr})$ in the present study. Figure 4 shows the solubility of $\mathrm{La}(\mathrm{OH})_{3}(\mathrm{cr})$ measured at $T_{\text {meas }}=25{ }^{\circ} \mathrm{C}$ after aging at $T_{\text {age }}=25,40,50,60$ and $90^{\circ} \mathrm{C}$ for 8 to 12 weeks. Since no significant change in the solubility values was observed after different aging periods, it was considered that the solubility reached a steady state after 8 weeks. It is noted that after aging at $60{ }^{\circ} \mathrm{C}$, the sample solutions kept at $25^{\circ} \mathrm{C}$ for longer days prior to the solubility measurement at $25^{\circ} \mathrm{C}$. No significant change was observed between different periods at $25^{\circ} \mathrm{C}$, also suggesting that a steady state has been achieved at $25^{\circ} \mathrm{C}$ after the solid phase transformation at $60{ }^{\circ} \mathrm{C}$. After aging at $25^{\circ} \mathrm{C}$, the La solubility at around $\mathrm{pH}_{\mathrm{c}} 7$, was observed to be near $2 \times 10^{-1} \mathrm{M}$, which corresponded to the total dissolution of the added $\mathrm{La}_{2} \mathrm{O}_{3}(\mathrm{cr})$ in the initial solid phase. The solubility then rapidly decreased with increasing $\mathrm{pH}_{\mathrm{c}}$ and was almost constant at $10^{-9} \mathrm{M}$ above $\mathrm{pH}_{\mathrm{c}} 10$, which is close to the detection limit of ICP-MS. After aging at $T_{\text {age }}=40,50$, and $60{ }^{\circ} \mathrm{C}$, the solubility values measured at $25{ }^{\circ} \mathrm{C}$ were observed to be similar to those aged at $25^{\circ} \mathrm{C}$, suggesting that no significant

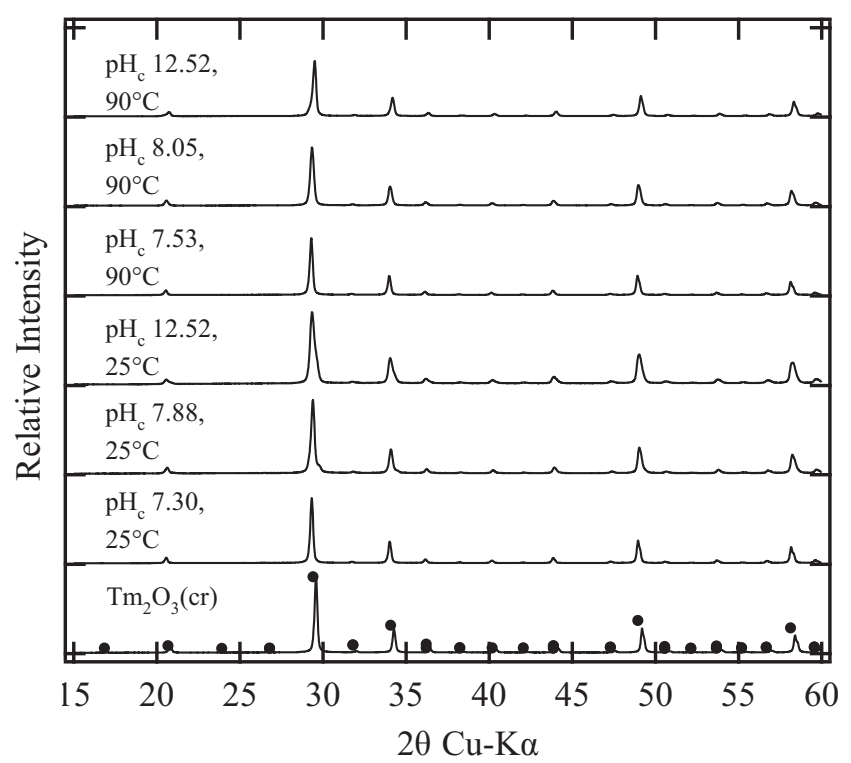

Figure 3. XRD patterns of the Tm solid phases after aging for 4 weeks at $\mathrm{pH}_{\mathrm{c}} 7.30,7.88$, and 12.52 at $25{ }^{\circ} \mathrm{C}$ and $\mathrm{pH}_{\mathrm{c}} 7.53,8.05$, and 12.52 at $90{ }^{\circ} \mathrm{C}$, together with that of $\mathrm{Tm}_{2} \mathrm{O}_{3}$ (cr) as the initial solid phase. Filled circles $(\bullet)$ represent the peaks from ICSD pattern of $\mathrm{Tm}_{2} \mathrm{O}_{3}$ (No. 33657). effect of the $T_{\text {age }}$ on the $\mathrm{La}(\mathrm{OH})_{3}(\mathrm{cr})$ solid phases below $T_{\text {age }}=$ $60{ }^{\circ} \mathrm{C}$, as summarized in Table 1.

On the other hand, after aging at $T_{\text {age }}=90{ }^{\circ} \mathrm{C}$, the obtained solubility values at $\mathrm{pH}_{\mathrm{c}} 8-9$ measured at $T_{\text {meas }}=25{ }^{\circ} \mathrm{C}$ were found to be lower by about 2 orders of magnitude than those obtained after aging at 25 to $60{ }^{\circ} \mathrm{C}$. As seen in Fig. 1, the XRD patterns of the $\mathrm{La}(\mathrm{OH})_{3}(\mathrm{cr})$ solid phase after aging at $90{ }^{\circ} \mathrm{C}$, were similar to those obtained after aging at $25{ }^{\circ} \mathrm{C}$. This indicated that there is no significant difference between the bulk structures of the solid phases aged at both temperatures. However, here we assumed a different solubility-limit-

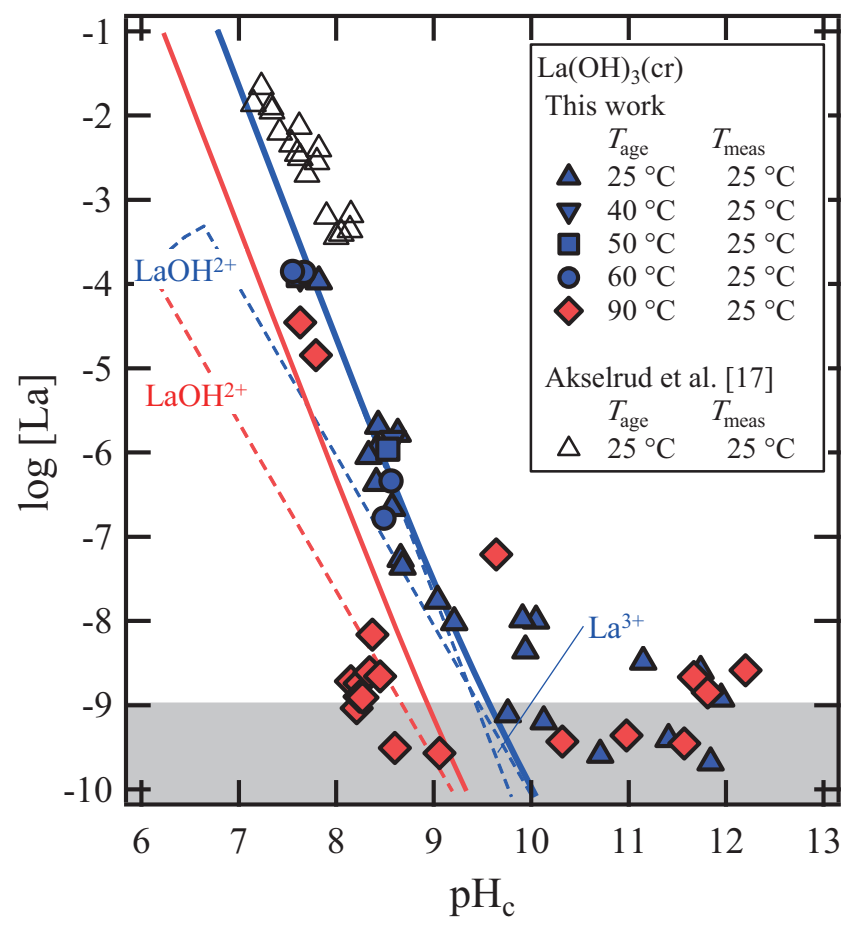

Figure 4. La solubilities measured at $T_{\text {meas }}=25{ }^{\circ} \mathrm{C}$ after aging at $T_{\text {age }}=25,40,50,60$, and $90^{\circ} \mathrm{C}$ for 8 and 12 weeks. The ionic strength was maintained at $I=0.1 \mathrm{M}$, and the solubilities were obtained after filtration through $3 \mathrm{kDa}$ membranes. The solid lines with blue and red colors represent the calculated solubility of $\mathrm{La}(\mathrm{OH})_{3}(\mathrm{cr})$ and $\mathrm{La}(\mathrm{OH})_{3}(\mathrm{cr}, 90)$, respectively. The broken lines with blue and red colors represent the contributions of $\mathrm{La}^{3+}$ and first hydrolysis species; $\mathrm{LaOH}^{2+}$. A gray field in the figure indicated the detection limit level of the ICP-MS.

TABLE 1: Summary of the solid phases investigated in the present study

\begin{tabular}{|c|c|c|c|c|}
\hline \multirow{2}{*}{ Aging Temp, $T_{\text {age }}$} & \multicolumn{4}{|c|}{ Measurement temp, $T_{\text {meas }}$} \\
\hline & $25^{\circ} \mathrm{C}$ & $40^{\circ} \mathrm{C}$ & $50{ }^{\circ} \mathrm{C}$ & $60^{\circ} \mathrm{C}$ \\
\hline $25^{\circ} \mathrm{C}$ & $\begin{array}{c}\mathrm{La}(\mathrm{OH})_{3}(\mathrm{cr})^{\mathrm{a}} \\
\mathrm{Eu}_{2} \mathrm{O}_{3}(\mathrm{cr})^{\mathrm{a}} \\
\mathrm{Tm}_{2} \mathrm{O}_{3}(\mathrm{cr})^{\mathrm{a}}\end{array}$ & - & - & - \\
\hline $40^{\circ} \mathrm{C}$ & $\begin{array}{c}\mathrm{La}(\mathrm{OH})_{3}(\mathrm{cr})^{\mathrm{b}} \\
\mathrm{Eu}_{2} \mathrm{O}_{3}(\mathrm{cr})^{\mathrm{b}} \\
\mathrm{Tm}_{2} \mathrm{O}_{3}(\mathrm{cr})^{\mathrm{b}}\end{array}$ & $\begin{array}{c}\mathrm{La}(\mathrm{OH})_{3}(\mathrm{cr})^{\mathrm{b}} \\
\mathrm{Eu}_{2} \mathrm{O}_{3}(\mathrm{cr})^{\mathrm{b}} \\
\mathrm{Tm}_{2} \mathrm{O}_{3}(\mathrm{cr})^{\mathrm{b}}\end{array}$ & - & - \\
\hline $50{ }^{\circ} \mathrm{C}$ & $\begin{array}{c}\mathrm{La}(\mathrm{OH})_{3}(\mathrm{cr})^{\mathrm{b}} \\
\mathrm{Eu}_{2} \mathrm{O}_{3}(\mathrm{cr})^{\mathrm{b}} \\
\mathrm{Tm}_{2} \mathrm{O}_{3}(\mathrm{cr})^{\mathrm{b}}\end{array}$ & $\begin{array}{c}\mathrm{La}(\mathrm{OH})_{3}(\mathrm{cr})^{\mathrm{b}} \\
\mathrm{Eu}_{2} \mathrm{O}_{3}(\mathrm{cr})^{\mathrm{b}} \\
\mathrm{Tm}_{2} \mathrm{O}_{3}(\mathrm{cr})^{\mathrm{b}}\end{array}$ & $\begin{array}{c}\mathrm{La}(\mathrm{OH})_{3}(\mathrm{cr})^{\mathrm{b}} \\
\mathrm{Eu}_{2} \mathrm{O}_{3}(\mathrm{cr})^{\mathrm{b}} \\
\mathrm{Tm}_{2} \mathrm{O}_{3}(\mathrm{cr})^{\mathrm{b}}\end{array}$ & - \\
\hline $60{ }^{\circ} \mathrm{C}$ & $\begin{array}{c}\mathrm{La}(\mathrm{OH})_{3}(\mathrm{cr})^{\mathrm{b}} \\
\mathrm{Eu}_{2} \mathrm{O}_{3}(\mathrm{cr})^{\mathrm{b}} \\
\mathrm{Tm}_{2} \mathrm{O}_{3}(\mathrm{cr})^{\mathrm{b}}\end{array}$ & $\begin{array}{c}\mathrm{La}(\mathrm{OH})_{3}(\mathrm{cr})^{\mathrm{b}} \\
\mathrm{Eu}_{2} \mathrm{O}_{3}(\mathrm{cr})^{\mathrm{b}} \\
\mathrm{Tm}_{2} \mathrm{O}_{3}(\mathrm{cr})^{\mathrm{b}}\end{array}$ & $\begin{array}{c}\mathrm{La}(\mathrm{OH})_{3}(\mathrm{cr})^{\mathrm{b}} \\
\mathrm{Eu}_{2} \mathrm{O}_{3}(\mathrm{cr})^{\mathrm{b}} \\
\mathrm{Tm}_{2} \mathrm{O}_{3}(\mathrm{cr})^{\mathrm{b}}\end{array}$ & $\begin{array}{c}\mathrm{La}(\mathrm{OH})_{3}(\mathrm{cr})^{\mathrm{b}} \\
\mathrm{Eu}_{2} \mathrm{O}_{3}(\mathrm{cr})^{\mathrm{b}} \\
\mathrm{Tm}_{2} \mathrm{O}_{3}(\mathrm{cr})^{\mathrm{b}}\end{array}$ \\
\hline $90^{\circ} \mathrm{C}$ & $\begin{array}{c}\mathrm{La}(\mathrm{OH})_{3}\left(\mathrm{cr}, 90^{\circ} \mathrm{C}\right)^{\mathrm{a}} \\
\mathrm{Eu}(\mathrm{OH})_{3}(\mathrm{cr})^{\mathrm{a}} \\
\mathrm{Tm}_{2} \mathrm{O}_{3}(\mathrm{cr})^{\mathrm{a}}\end{array}$ & 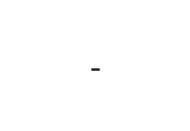 & 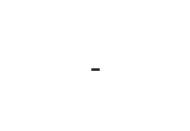 & 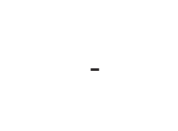 \\
\hline
\end{tabular}

a) The solid phase was confirmed by the XRD patterns.

b) The solid phase was assumed from the observed solubilities. 
ing solid phase, $\mathrm{La}(\mathrm{OH})_{3}\left(\mathrm{cr}, 90^{\circ} \mathrm{C}\right.$ aged $)$, after aging at $90{ }^{\circ} \mathrm{C}$, based on the observations in the solubility experiment. The solubility values after aging at $90{ }^{\circ} \mathrm{C}$ at $\mathrm{pH}_{\mathrm{c}}<8$ were rather scattered and approaching to those obtained after aging at 25 ${ }^{\circ} \mathrm{C}$, as shown in Fig. 4. After aging at $90{ }^{\circ} \mathrm{C}$ for given periods, the sample solutions were cooled down to $25^{\circ} \mathrm{C}$ before the $\mathrm{pH}_{\mathrm{c}}$ and solubility measurements. During the cooling time for $25^{\circ} \mathrm{C}, \mathrm{La}(\mathrm{OH})_{3}\left(\mathrm{cr}, 90^{\circ} \mathrm{C}\right.$ aged $)$ may begin transformation to $\mathrm{La}(\mathrm{OH})_{3}(\mathrm{cr})$ at $25^{\circ} \mathrm{C}$, especially in the lower $\mathrm{pH}$ region where higher solubility is expected. In the region at $\mathrm{pH}_{\mathrm{c}}>9$, the solubility values after aging at $90{ }^{\circ} \mathrm{C}$ were near the detection limit of ICP-MS, similar to those obtained after aging at $25^{\circ} \mathrm{C}$.

In literatures, a number of studies have investigated the solubility of La hydroxides $\left(\mathrm{La}(\mathrm{OH})_{3}(\mathrm{~s})\right)$ at $25{ }^{\circ} \mathrm{C}$ or room temperatures under varying experimental conditions of preparation method, medium, and aging durations [4, 17, 21-23, 25, 35-39]. Daikonov et al. $[25,26]$ have comprehensively reviewed the solubility studies on lanthanide hydroxides and categorized the $\mathrm{La}(\mathrm{OH})_{3}(\mathrm{~s})$ solid phases into two groups; freshly precipitated and slightly aged $\mathrm{La}(\mathrm{OH})_{3}(\mathrm{~s})$ (within 1 day), and long term aged $\mathrm{La}(\mathrm{OH})_{3}(\mathrm{~s})$. The experimental conditions of aging at $25^{\circ} \mathrm{C}$, for 8 and 12 weeks in the present study, are similar to those for the long-term aging of $\mathrm{La}(\mathrm{OH})_{3}(\mathrm{~s})$, in studies reviewed by Daikonov et al. $[25,26]$. The solubility values reported in Akselrud et al. plotted in Fig. 4 were obtained after aging at $25{ }^{\circ} \mathrm{C}$ for 166 days by an oversaturation method [17]. The solubility values from their method [17] represented the points of starting precipitation after adding $\mathrm{NaOH}$ solutions to La solution, while limiting the $\mathrm{pH}$ range to $\mathrm{pH}_{\mathrm{c}} 7-8$, whereas the solubility values in the present study were obtained from an undersaturation approach at a wider $\mathrm{pH}$ range. Since the $\mathrm{pH}_{\mathrm{c}}$ range of our experiment does not really overlap with that in the studies by Akselrud et al. [17], the difference in the solubility values can be attributed to the difference in experimental conditions.

3.2.2. Eu Solubilities measured at $25^{\circ} \mathrm{C}$ after aging at 25 to $90{ }^{\circ} \mathrm{C}$. As confirmed by the XRD patterns, the solid phase remained $\mathrm{Eu}_{2} \mathrm{O}_{3}(\mathrm{cr})$ after aging at $25^{\circ} \mathrm{C}$, while it converted to $\mathrm{Eu}(\mathrm{OH})_{3}(\mathrm{cr})$ after aging at $90{ }^{\circ} \mathrm{C}$. The $\Delta_{\mathrm{f}} H_{\mathrm{m}}^{\circ}$ and $S_{\mathrm{m}}^{\circ}$ values for $\mathrm{Eu}_{2} \mathrm{O}_{3}(\mathrm{cr})$ were reported to be $\Delta_{\mathrm{f}} H_{\mathrm{m}}^{\circ}=-1650.4 \pm 4.0 \mathrm{~kJ} / \mathrm{mol}$ and $S_{\mathrm{m}}^{\circ}=143.5 \pm 0.5 \mathrm{~J} / \mathrm{K} / \mathrm{mol}$ [29]. Combined with the $\Delta_{\mathrm{f}} H_{\mathrm{m}}^{\circ}$ and $S_{\mathrm{m}}^{\circ}$ for $\mathrm{Eu}^{3+}$ and $\mathrm{H}_{2} \mathrm{O}[2,4], \Delta_{\mathrm{r}} G_{\mathrm{m}}^{\circ}=-154.64 \mathrm{~kJ} / \mathrm{mol}$ and $\log K_{\mathrm{s}}^{\circ}=$ 27.09 were obtained at $25^{\circ} \mathrm{C}$ for $1 / 2 \mathrm{Eu}_{2} \mathrm{O}_{3}(\mathrm{cr})+3 \mathrm{H}^{+} \rightleftharpoons \mathrm{Eu}^{3+}+$ $3 / 2 \mathrm{H}_{2} \mathrm{O}$. Although the calculated $K_{\mathrm{s}}^{\circ}$ was found to be orders of magnitude larger than those reported for $\mathrm{Eu}(\mathrm{OH})_{3}(\mathrm{cr})\left(\log K_{\mathrm{s}}^{\circ}=\right.$ 16.48) [4], the bulk structure remained $\mathrm{Eu}_{2} \mathrm{O}_{3}$ (cr) after aging in the sample solutions at $25^{\circ} \mathrm{C}$. In contrast to the case of La, the solid phase transformation may be kinetically hindered when started from $\mathrm{Eu}_{2} \mathrm{O}_{3}(\mathrm{cr})$ in aqueous solutions under the present investigated conditions. Fig. 5 shows the Eu solubility values measured at $T_{\text {meas }}=25^{\circ} \mathrm{C}$ after aging at $T_{\text {age }}=25,40,50,60$, and $90{ }^{\circ} \mathrm{C}$ for up to 8 weeks. The obtained results showed there was no significant change in solubility for the entire aging periods, suggesting that a steady state had been achieved. After aging at $60{ }^{\circ} \mathrm{C}$, no significant change was observed between different cooling periods at $T_{\text {meas }}=25^{\circ} \mathrm{C}$, also suggesting that a steady state has been achieved at $25^{\circ} \mathrm{C}$ after the solid phase transformation at $60{ }^{\circ} \mathrm{C}$. The solubility of $\mathrm{Eu}_{2} \mathrm{O}_{3}$ (cr) obtained after aging at $25^{\circ} \mathrm{C}$ was around $10^{-5} \mathrm{M}$ at $\mathrm{pH}_{\mathrm{c}} 8$, and then decreased with the increasing $\mathrm{pH}_{\mathrm{c}}$. As shown in Fig. 5, the solubility values after aging at $T_{\text {age }}=40,50$, and $60^{\circ} \mathrm{C}$ were plotted within the range of the scattering data aged at $T_{\text {age }}=$ $25{ }^{\circ} \mathrm{C}$. This suggested that the aging temperature up to $60^{\circ} \mathrm{C}$ had little impact on the solid phase transformation, as summarized in Table 1. On the other hand, the solubility of $\mathrm{Eu}(\mathrm{OH})_{3}(\mathrm{cr})$ obtained after aging at $90{ }^{\circ} \mathrm{C}$ was lower by about one order of magnitude, than that of $\mathrm{Eu}_{2} \mathrm{O}_{3}(\mathrm{cr})$ at $\mathrm{pH}_{\mathrm{c}}$ 8. For $\mathrm{pHc}>9$, the solubility values for both the solid phases were

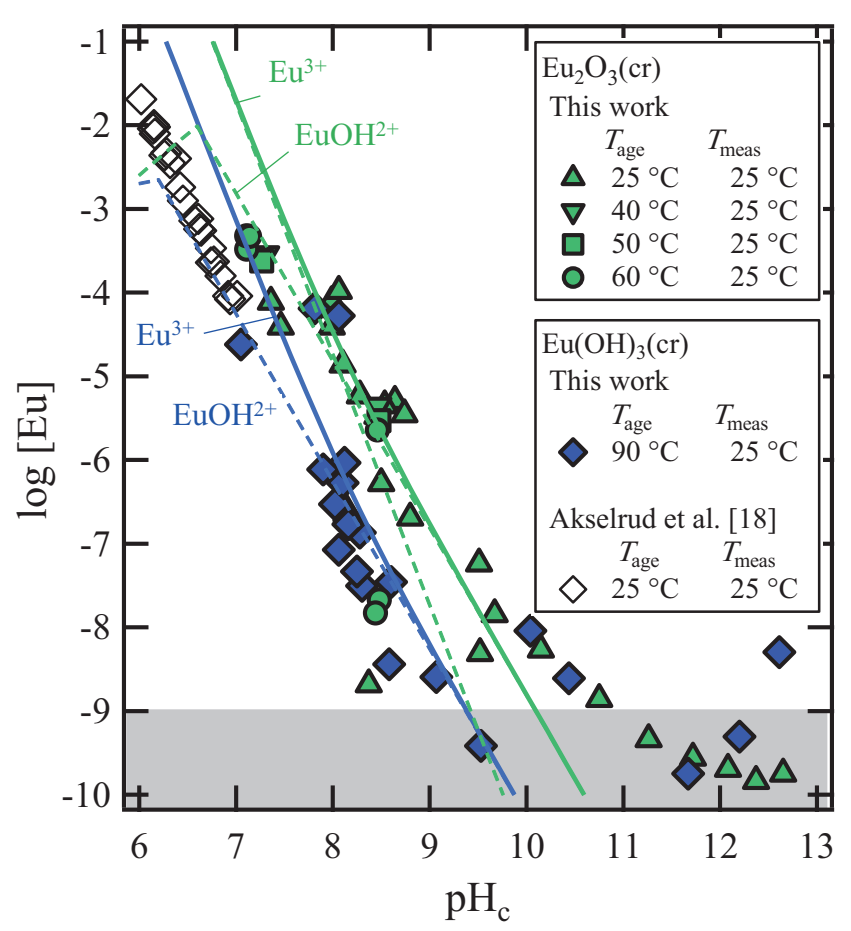

Figure 5. Eu solubilities measured at $T_{\text {meas }}=25^{\circ} \mathrm{C}$ after aging at $T_{\text {age }}$ $=25,40,50,60$, and $90^{\circ} \mathrm{C}$ for 4 and 8 weeks. The ionic strength was maintained at $I=0.1 \mathrm{M}$ and the solubilities were obtained after filtration through $3 \mathrm{kDa}$ membranes. The solid lines with green and blue colors represent the calculated solubility of $\mathrm{Eu}_{2} \mathrm{O}_{3}(\mathrm{cr})$ and $\mathrm{Eu}(\mathrm{OH})_{3}(\mathrm{cr})$, respectively. The broken lines with green and blue colors represent the contributions of $\mathrm{Eu}^{3+}$ and first hydrolysis species; $\mathrm{EuOH}^{2+}$. A gray field in the figure indicated the detection limit level of the ICP-MS.

observed to be in the range of detection limit of ICP-MS.

The solubility of $\mathrm{Eu}(\mathrm{OH})_{3}(\mathrm{~s})$ has been investigated in several literatures $[4,15,16,18,24,25,39-42]$. Akselrud and Ermolenko [18] observed starting points of precipitation by adding $\mathrm{NaOH}$ solutions to Eu solution in certain concentrations. The $\mathrm{pH}$ of these sample solutions starting to precipitate was measured several times for up to 150 days, to determine the solubility product values [18]. Moeller et al. also investigated the solubility limit of $\mathrm{Eu}(\mathrm{OH})_{3}(\mathrm{~s})$ by measuring the starting points of precipitations $[15,16]$. The Eu concentrations against $\mathrm{pH}$ of starting points for precipitation after 50 days [18] were plotted in Fig. 5 for comparison. Although the pH range of the present study and the literature do not overlap, the estimated trends from the measured solubility values of $\mathrm{Eu}(\mathrm{OH})_{3}(\mathrm{~s})$, seem to be in agreement with those seen in previous studies.

3.2.3. Tm solubilities measured at $25^{\circ} \mathrm{C}$ after aging at 25 to $90{ }^{\circ} \mathrm{C}$. The XRD patterns of the Tm solid phases after aging at 25 and $90^{\circ} \mathrm{C}$ suggested that the solid phases remained as $\mathrm{Tm}_{2} \mathrm{O}_{3}$ (cr) during the investigated periods. The reported values of $\Delta_{\mathrm{f}} H_{\mathrm{m}}^{\circ}=-1889.3 \pm 5.7 \mathrm{~kJ} / \mathrm{mol}$ and $S_{\mathrm{m}}^{\circ}=139.7 \pm 0.4 \mathrm{~J} / \mathrm{K} /$ mol for $\mathrm{Tm}_{2} \mathrm{O}_{3}$ (cr) [29] resulted in $\Delta_{\mathrm{r}} G_{\mathrm{m}}^{\circ}=-129.39 \mathrm{~kJ} / \mathrm{mol}$, hence $\log K_{\mathrm{s}}^{\circ}=22.67$ for $1 / 2 \mathrm{Tm}_{2} \mathrm{O}_{3}(\mathrm{cr})+3 \mathrm{H}^{+} \rightleftharpoons \mathrm{Tm}^{3+}+3 / 2$ $\mathrm{H}_{2} \mathrm{O}$, combined with the $\Delta_{\mathrm{f}} H_{\mathrm{m}}^{\circ}$ and $S_{\mathrm{m}}^{\circ}$ for $\mathrm{Tm}^{3+}$ and $\mathrm{H}_{2} \mathrm{O}[2,4]$. Although the calculated $K_{\mathrm{s}}^{\circ}$ value was less than those for $\mathrm{Eu}_{2} \mathrm{O}_{3}(\mathrm{cr})$ and $\mathrm{La}_{2} \mathrm{O}_{3}(\mathrm{cr})$, the value was found to be still orders of magnitude larger than those of reported $\log K_{\mathrm{s}}^{\circ}=15.56$ for $\mathrm{Tm}(\mathrm{OH})_{3}(\mathrm{cr})$ [4]. However, similarly to the case of $\mathrm{Eu}_{2} \mathrm{O}_{3}(\mathrm{cr})$, the solid phase transformation was thought to be kinetically hindered under the experimental condition in the present study. In Fig. 6, the Tm solubilities measured at $T_{\text {meas }}=25^{\circ} \mathrm{C}$ after aging at $T_{\text {age }}=25,40,50,60$, and $90^{\circ} \mathrm{C}$ up to 8 weeks were plotted. No significant difference was observed after aging different aging temperatures, indicating that the initial 


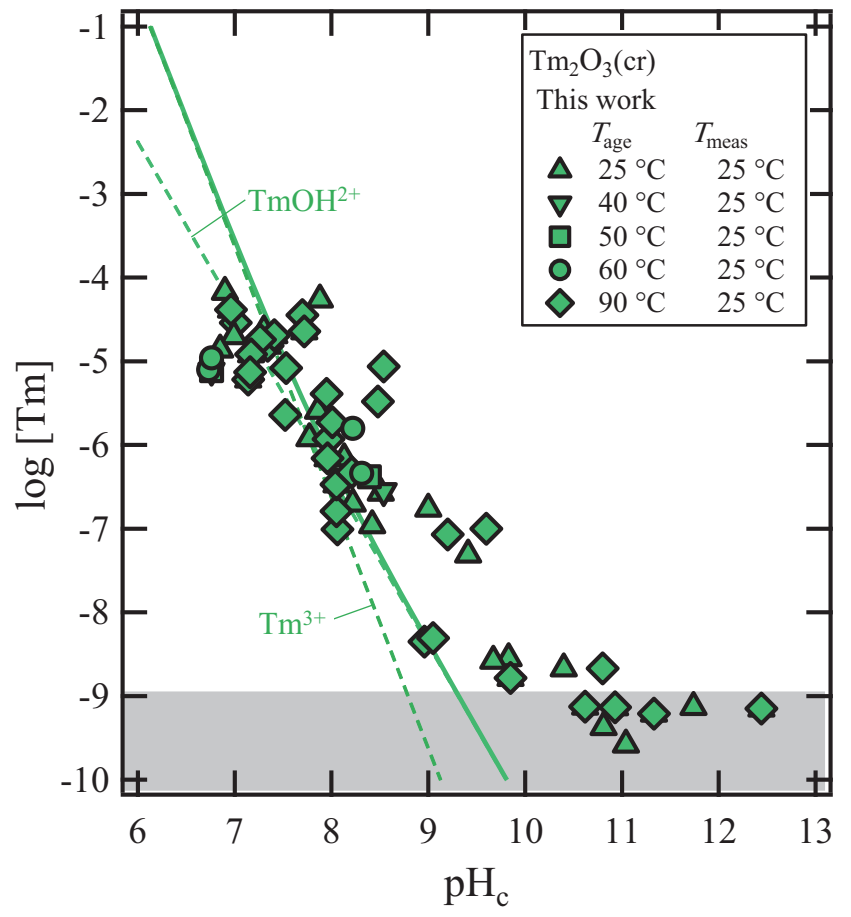

Figure 6. Tm solubilities measured at $T_{\text {meas }}=25{ }^{\circ} \mathrm{C}$ after aging at $T_{\text {age }}=25,40,50,60$, and $90^{\circ} \mathrm{C}$ for 4 and 8 weeks. The ionic strength was maintained at $I=0.1 \mathrm{M}$, and the solubilities were obtained after filtration through $3 \mathrm{kDa}$ membranes. The solid line with green color represents the calculated solubility of $\mathrm{Tm}_{2} \mathrm{O}_{3}(\mathrm{cr})$. The broken lines with green color represent the contributions of $\mathrm{Tm}^{3+}$ and first hydrolysis species; $\mathrm{TmOH}^{2+}$. A gray field in the figure indicated the detection limit level of the ICP-MS.
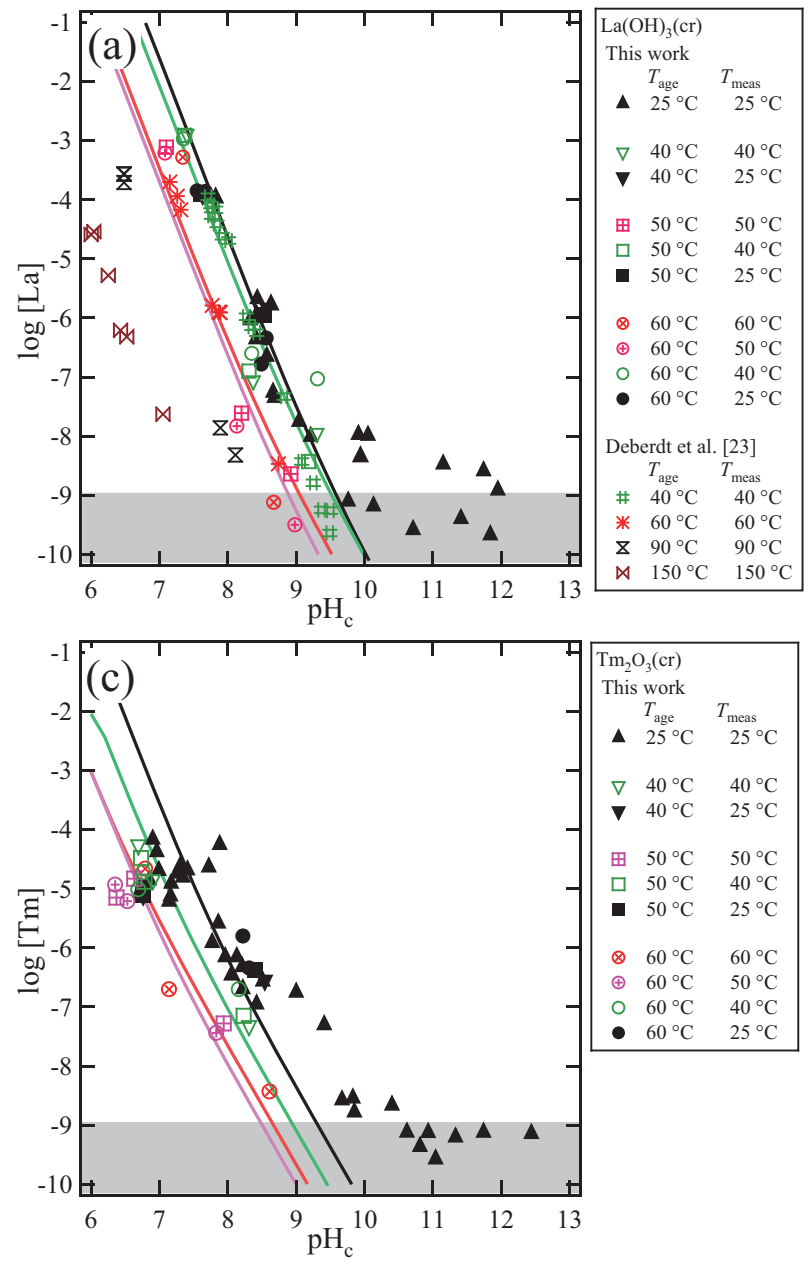

$\mathrm{Tm}_{2} \mathrm{O}_{3}$ (cr) was stable up to $T_{\text {age }}=90{ }^{\circ} \mathrm{C}$. The solubility of $\mathrm{Tm}_{2} \mathrm{O}_{3}$ (cr) measured at $25^{\circ} \mathrm{C}$ was approximately $10^{-5} \mathrm{M}$ at $\mathrm{pH}_{\mathrm{c}}$ 7, after which it gradually decreased with an increase in $\mathrm{pH}_{\mathrm{c}}$. In the region where $\mathrm{pH}_{\mathrm{c}}>10$, solubility plots were observed close to $10^{-9} \mathrm{M}$ of the detection limit.

In literature, only one study has reported the experimental solubility data for $\operatorname{Tm}(\mathrm{OH})_{3}(\mathrm{~s})$ [15]. Moeller and Kremers [15] measured the starting point for precipitation by adding $\mathrm{NaOH}$ to Tm solutions, and assumed that the precipitate was $\mathrm{Tm}(\mathrm{OH})_{3}(\mathrm{~s})$. On the other hand, the solubility experiment in the present study started from $\mathrm{Tm}_{2} \mathrm{O}_{3}(\mathrm{cr})$, by adding $\mathrm{Tm}_{2} \mathrm{O}_{3}(\mathrm{cr})$ into the sample solutions as an initial solid phase. Further discussions on this are given in the following sections.

3.3. Solubilities measured at 25 to $60{ }^{\circ} \mathrm{C}$. After aging the $\mathrm{La}, \mathrm{Eu}$, and Tm sample solutions at $T_{\text {age }}=25,40,50$, and $60^{\circ} \mathrm{C}$ for 4 to 12 weeks, their solubilities were investigated under different measurement temperature $\left(T_{\text {meas }}\right)$ conditions at 25,40 , 50 , and $60{ }^{\circ} \mathrm{C}$ (See Table 1). As described above, the sample tubes after aging at a certain temperature were kept in thermostatted baths at $25,40,50$, and $60{ }^{\circ} \mathrm{C}$ for 1 day, then $\mathrm{pH}_{\mathrm{c}}$ was measured and the supernatant of the sample solutions were ultrafiltrated at a fixed $T_{\text {meas }}$ condition. The obtained La, Eu, and Tm solubilities are presented in Fig. 7. Contrary to the effect of aging temperature, the $\mathrm{La}, \mathrm{Eu}$, and Tm solubilities decreased with increasing $T_{\text {meas }}$ at the same $\mathrm{pH}$ conditions. In Fig. 7(a), the solubilities of $\mathrm{La}(\mathrm{OH})_{3}(\mathrm{~s})$ measured at 40, 60, 90, and $150{ }^{\circ} \mathrm{C}$ by Deberdt et al. [23] were plotted for comparison. The solubility values in the present study were in agreement with the reported results at the same $T_{\text {meas }}$ condition. Since no significant difference by the aging temperatures up to $60{ }^{\circ} \mathrm{C}$

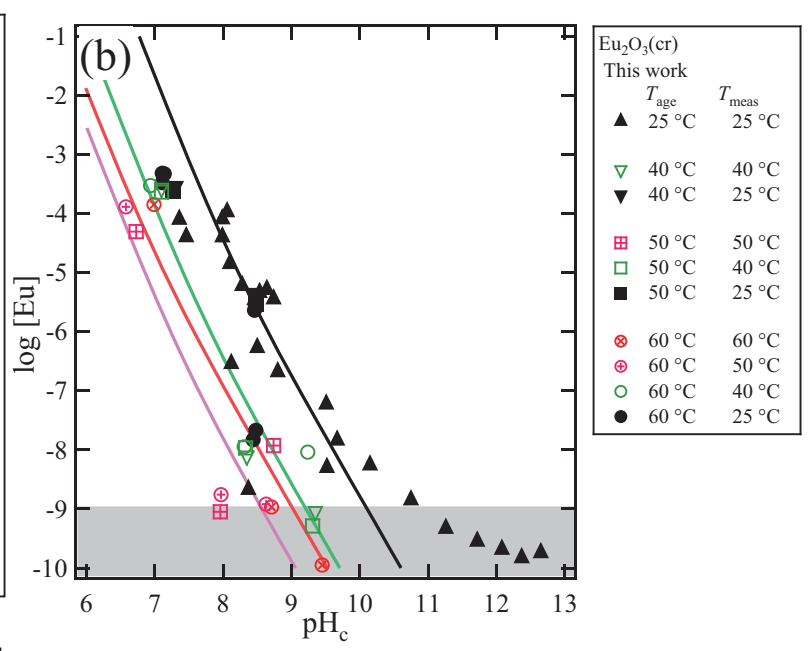

Figure 7. Solubilities of (a) $\mathrm{La}(\mathrm{OH})_{3}(\mathrm{cr})$, (b) $\mathrm{Eu}_{2} \mathrm{O}_{3}(\mathrm{cr})$, and (c) $\mathrm{Tm}_{2} \mathrm{O}_{3}(\mathrm{cr})$ measured at $T_{\text {meas }}=25,40,50$, and $60{ }^{\circ} \mathrm{C}$ after aging at $T_{\text {age }}=25$, 40, 50, and $60{ }^{\circ} \mathrm{C}$ for 4 to 12 weeks. The ionic strength was maintained at $I=0.1 \mathrm{M}$, and the solubilities were obtained after filtration through $3 \mathrm{kDa}$ membranes. The solid lines with black, green, pink, and red colors represent the calculated solubilities of (a) $\mathrm{La}(\mathrm{OH})_{3}(\mathrm{cr}),(\mathrm{b}) \mathrm{Eu}_{2} \mathrm{O}_{3}(\mathrm{cr})$, and $(\mathrm{c})$ $\mathrm{Tm}_{2} \mathrm{O}_{3}(\mathrm{cr})$ measured at $T_{\text {meas }}=25,40,50$, and $60{ }^{\circ} \mathrm{C}$, respectively. A gray field in the figure indicated the detection limit level of the ICP-MS. 
was observed for each element, we assumed that the solid phases in Fig. 7 were $\mathrm{La}(\mathrm{OH})_{3}(\mathrm{cr}), \mathrm{Eu}_{2} \mathrm{O}_{3}(\mathrm{cr})$, and $\mathrm{Tm}_{2} \mathrm{O}_{3}(\mathrm{cr})$, regardless of the aging temperatures. The solubilities at each $T_{\text {meas }}$ are analyzed to determine the $K_{\mathrm{s}}^{\circ}$ values at respective $T_{\text {meas }}$ to discuss their temperature dependences in the following section.

\subsection{Thermodynamic analysis of the solubility data.}

3.4.1. Thermodynamic model for the solubility of $\mathrm{Ln}_{2} \mathrm{O}_{3}(\mathrm{cr})$ and $\operatorname{Ln}(\mathrm{OH})_{3}(\mathbf{c r})$. In the systems for $\mathrm{La}, \mathrm{Eu}$, and Tm solubilities in neutral to alkaline $\mathrm{pH}$ region after aging at $T_{\text {age }}=25$ to $90{ }^{\circ} \mathrm{C}$, oxide $\left(\mathrm{Ln}_{2} \mathrm{O}_{3}(\mathrm{cr})\right)$ or hydroxide $\left(\mathrm{Ln}(\mathrm{OH})_{3}(\mathrm{cr})\right)(\mathrm{Ln}=\mathrm{La}$, $\mathrm{Eu}, \mathrm{Tm})$ solid phases were observed depending on the elements and aging temperatures. The dissolution and precipitation reactions of $\mathrm{Ln}_{2} \mathrm{O}_{3}(\mathrm{cr})$ and $\mathrm{Ln}(\mathrm{OH})_{3}(\mathrm{cr})$ can be described respectively by the following equations:

$$
\begin{aligned}
& \frac{1}{2} \mathrm{Ln}_{2} \mathrm{O}_{3}(\mathrm{cr})+3 \mathrm{H}^{+} \rightleftharpoons \mathrm{Ln}^{3+}+\frac{3}{2} \mathrm{H}_{2} \mathrm{O} \\
& K_{s}\left(\mathrm{Ln}_{2} \mathrm{O}_{3}(\mathrm{cr})\right)=\frac{\left[\mathrm{Ln}^{3+}\right]}{\left[\mathrm{H}^{+}\right]^{3}} \\
& \mathrm{Ln}(\mathrm{OH})_{3}(\mathrm{cr})+3 \mathrm{H}^{+} \rightleftharpoons \mathrm{Ln}^{3+}+3 \mathrm{H}_{2} \mathrm{O} \\
& K_{s}\left(\mathrm{Ln}(\mathrm{OH})_{3}(\mathrm{cr})\right)=\frac{\left[\mathrm{Ln}^{3+}\right]}{\left[\mathrm{H}^{+}\right]^{3}}
\end{aligned}
$$

where $K_{\mathrm{s}}\left(\mathrm{Ln}_{2} \mathrm{O}_{3}(\mathrm{cr})\right)$ and $K_{\mathrm{s}}\left(\mathrm{Ln}(\mathrm{OH})_{3}(\mathrm{cr})\right)$ represent the solubility products of $\mathrm{Ln}_{2} \mathrm{O}_{3}(\mathrm{cr})$ and $\mathrm{Ln}(\mathrm{OH})_{3}(\mathrm{cr})$, respectively.

In the aqueous phase, the hydrolysis reactions and the hydrolysis constants $\left({ }^{*} \beta_{\mathrm{n}} ; \mathrm{n}=1-3\right)$ were given as follows:

$$
\begin{aligned}
& \mathrm{Ln}^{3+}+n \mathrm{H}_{2} \mathrm{O} \rightleftharpoons \mathrm{Ln}(\mathrm{OH})_{n}^{(3-n)^{+}}+n \mathrm{H}^{+} \\
& { }^{*} \beta_{\mathrm{n}}=\frac{\left[\mathrm{Ln}(\mathrm{OH})_{\mathrm{n}}^{(3-n)+}\right]\left[\mathrm{H}^{+}\right]^{n}}{\left[\mathrm{Ln}^{3+}\right]}
\end{aligned}
$$

The solubility as a total Ln concentration ([La $]_{\text {tot }}$ ) can be described as:

$$
\begin{aligned}
{[\mathrm{Ln}]_{\text {tot }} } & =\left[\mathrm{Ln}^{3+}\right]+\left[\mathrm{LnOH}^{2+}\right]+\left[\mathrm{Ln}(\mathrm{OH})_{2}^{+}\right]+\left[\mathrm{Ln}(\mathrm{OH})_{3}(\mathrm{aq})\right] \\
& =\left[\mathrm{Ln}^{3+}\right]\left(1+\frac{{ }^{*} \beta_{1}}{\left[\mathrm{H}^{+}\right]}+\frac{{ }^{*} \beta_{2}}{\left[\mathrm{H}^{+}\right]^{2}}+\frac{{ }^{*} \beta_{3}}{\left[\mathrm{H}^{+}\right]^{3}}\right) \\
& =K_{\mathrm{s}}\left(\left[\mathrm{H}^{+}\right]^{3}+{ }^{*} \beta_{1}\left[\mathrm{H}^{+}\right]^{2}+{ }^{*} \beta_{2}\left[\mathrm{H}^{+}\right]+{ }^{*} \beta_{3}\right)
\end{aligned}
$$

According to the specific ion interaction theory (SIT) method, the solubility product $\left(K_{\mathrm{s}}\right)$ and hydrolysis constants $\left({ }^{*} \beta_{\mathrm{n}}\right)$ can be corrected to $I=0$ by the following equations;

$$
\begin{aligned}
& \log K_{\mathrm{s}}=\log K_{\mathrm{s}}^{\circ}+6 D-I_{m} \cdot\left\{\varepsilon\left(\mathrm{Ln}^{3+}, \mathrm{ClO}_{4}^{-}\right)-3 \varepsilon\left(\mathrm{H}^{+}, \mathrm{ClO}_{4}^{-}\right)\right\} \\
& \log ^{*} \beta_{\mathrm{n}}=\log ^{*} \beta_{\mathrm{n}}^{\circ}+\left\{(3-n)^{2}+n-9\right\} D+n \log a_{\mathrm{H}_{2} \mathrm{O}^{-}} \\
& I_{\mathrm{m}} \cdot\left\{\varepsilon\left(\mathrm{Ln}(\mathrm{OH})_{n}^{(3-n)+}, \mathrm{ClO}_{4}^{-}\right)+n \varepsilon\left(\mathrm{H}^{+}, \mathrm{ClO}_{4}^{-}\right)-\varepsilon\left(\mathrm{Ln}^{3+}, \mathrm{ClO}_{4}^{-}\right)\right\},
\end{aligned}
$$

where $K_{\mathrm{s}}^{\circ},{ }^{*} \beta_{\mathrm{n}}^{\circ}, I_{\mathrm{m}}, a_{\mathrm{H}_{2} \mathrm{O}}$, and $D$ are the solubility product, hydrolysis constant at $I=0$, the ionic strength, activity of water, and the Debye-Hückel term at $25^{\circ} \mathrm{C}$, respectively. $\varepsilon\left(\mathrm{Ln}(\mathrm{OH})_{n}^{(3-n)^{+}}\right.$, $\left.\mathrm{ClO}_{4}^{-}\right), \varepsilon\left(\mathrm{Ln}^{3+}, \mathrm{ClO}_{4}^{-}\right)$, and $\varepsilon\left(\mathrm{H}^{+}, \mathrm{ClO}_{4}^{-}\right)$represent ion interaction coefficients for each species.

Based on the integrated van't Hoff equation, the $K_{\mathrm{s}}$ and * $\beta_{\mathrm{n}}$ can be expressed as a function of $T_{\text {meas }}$,

$$
\begin{aligned}
& \log K_{\mathrm{s}}\left(T_{\text {meas }}\right)=\log K_{\mathrm{s}}\left(T_{0}\right)+ \\
& \frac{\Delta_{\mathrm{r}} H_{\mathrm{m}}\left(\operatorname{Ln}_{2} \mathrm{O}_{3}(\mathrm{cr}) \text { or } \operatorname{Ln}(\mathrm{OH})_{3}(\mathrm{cr})\right)}{R \ln 10}\left(\frac{1}{T_{0}}-\frac{1}{T_{\text {meas }}}\right)
\end{aligned}
$$

$$
\begin{aligned}
& \log ^{*} \beta_{\mathrm{n}}\left(T_{\text {meas }}\right)= \\
& \quad \log ^{*} \beta_{\mathrm{n}}\left(T_{0}\right)+\frac{\Delta_{\mathrm{r}} H_{\mathrm{m}}\left(\operatorname{Ln}(\mathrm{OH})_{n}^{(3-n)+}\right)}{R \ln 10}\left(\frac{1}{T_{0}}-\frac{1}{T_{\text {meas }}}\right)
\end{aligned}
$$

where $R$ and $T_{0}$ are the universal gas constant, and $298 \mathrm{~K}\left(25^{\circ} \mathrm{C}\right)$, respectively.

\subsubsection{Solubility product of $\mathrm{Ln}_{2} \mathrm{O}_{3}(\mathrm{cr})$ and $\mathrm{Ln}(\mathrm{OH})_{3}(\mathrm{cr})$ at} $T_{\text {meas }}=25$ to $60{ }^{\circ} \mathrm{C}$. The solubility data for $\mathrm{La}, \mathrm{Eu}$, and $\mathrm{Tm}$ in $0.1 \mathrm{M} \mathrm{NaClO}_{4}$ solution at $T_{\text {meas }}=25$ to $60{ }^{\circ} \mathrm{C}$ were analyzed based on Eq. (7) with a combination of the ionic strength correction by SIT shown in Eqs. (8) and (9) to determine the solubility product of $\mathrm{Ln}_{2} \mathrm{O}_{3}(\mathrm{cr})$ or $\mathrm{Ln}(\mathrm{OH})_{3}(\mathrm{cr})$ at respective $T_{\text {meas }}$. Since the solubility values at $\mathrm{pH}_{\mathrm{c}}>10$ were close to the detection limit of ICP-MS, the solubility data used in the analysis were limited at $\mathrm{pH}_{\mathrm{c}}<10$. Therefore, only $\mathrm{Ln}^{3+}$ and first hydrolysis species of $\mathrm{LnOH}^{2+}$ in Eq. (7) was taken into account in the analysis. It is note that the ion interaction coefficient values was fixed as $\varepsilon\left(\mathrm{Ln}(\mathrm{OH})_{n}^{(3-n)+}, \mathrm{ClO}_{4}^{-}\right)=0.39$ and $\varepsilon\left(\mathrm{Ln}^{3+}, \mathrm{ClO}_{4}^{-}\right)$ $=0.47$ [4] for $\mathrm{La}, \mathrm{Eu}$, and $\mathrm{Tm}$, and $\varepsilon\left(\mathrm{H}^{+}, \mathrm{ClO}_{4}^{-}\right)=0.14$ [2]. These values were assumed constant against $T_{\text {meas }}$ due to the lacking data on their temperature dependence, while the $D$ value was corrected based on the temperature correction in [2]. No polynuclear species was taken into account in the analysis of the solubility data. The sample solutions were prepared by an undersaturation method, and the measured solubility values were mostly limited to lower than $10^{-4} \mathrm{M}$, where contribution of polynuclear species was considered to be negligible.

In the present analysis, the ${ }^{*} \beta_{1}$ value was treated as a fixed parameter. The ${ }^{*} \beta_{1}$ values for lanthanide elements have been reported in many literatures [22,38,39,43-52] and summarized in $[4,25-28]$. Although some scatterings were found in the literatures, the reported or re-calculated ${ }^{*} \beta_{1}$ values for $25^{\circ} \mathrm{C}$ at $I$ $=0$ were relatively in good agreement and Brown and Ekberg [4] have selected the recommended " $\beta_{1}$ values for the lanthanide series. Hence, the ${ }^{*} \beta_{1}$ value at $25{ }^{\circ} \mathrm{C}$ was taken from [4] and used as a fixed parameter in the present analysis. Several literatures have also investigated the ${ }^{*} \beta_{1}$ value at different temperatures $[47,49,50]$. For example, Klungness and Byrne [50] determined the ${ }^{*} \beta_{1}$ values for yttrium and rare earth elements in a combination of potentiometric and spectroscopic experiments at 25 to $55^{\circ} \mathrm{C}$. The $\log { }^{*} \beta_{1}$ value for $\mathrm{La}^{3+}+\mathrm{H}_{2} \mathrm{O} \rightleftharpoons$ $\mathrm{LaOH}^{2+}+\mathrm{H}^{+}$increased with an increase of temperature and the enthalpy value was obtained based on the analysis using the van't Hoff equation for lighter to heavier lanthanide elements [50]. In the present analysis, the ${ }^{*} \beta_{1}$ values for $\mathrm{La}$, Eu, and $\mathrm{Tm}$ at 40,50 , and $60^{\circ} \mathrm{C}$ were calculated from the enthalpy values reported in [50] and used as fixed parameters after the ionic strength correction.

The $K_{\mathrm{s}}\left(\mathrm{La}(\mathrm{OH})_{3}(\mathrm{cr})\right), K_{\mathrm{s}}\left(\mathrm{Eu}_{2} \mathrm{O}_{3}(\mathrm{cr})\right)$, and $K_{\mathrm{s}}\left(\mathrm{Tm}_{2} \mathrm{O}_{3}(\mathrm{cr})\right)$ at $T_{\text {meas }}=25,40,50$, and $60{ }^{\circ} \mathrm{C}$ were determined by the least square fitting analysis of the solubility data by treating the ${ }^{*} \beta_{1}$ values as fixed parameters. The obtained values are summarized in Table 2 and the calculated solubility curves based on the values in Table 2 are shown in Figs. 4-7. The $K_{\mathrm{s}}\left(\mathrm{La}(\mathrm{OH})_{3}(\mathrm{cr})\right), K_{\mathrm{s}}\left(\mathrm{Eu}_{2} \mathrm{O}_{3}(\mathrm{cr})\right)$, and $K_{\mathrm{s}}\left(\mathrm{Tm}_{2} \mathrm{O}_{3}(\mathrm{cr})\right)$ at $T_{\text {meas }}=$ $25,40,50$, and $60{ }^{\circ} \mathrm{C}$ were plotted as a function of the inverse of absolute temperature in Fig. 8, together with the literature values. For $\mathrm{La}(\mathrm{OH})_{3}(\mathrm{cr})$ aged at 25 to $60{ }^{\circ} \mathrm{C}$, the $\log K_{\mathrm{s}}$ value 
was determined to be $\log K_{\mathrm{s}}^{\circ}=19.0 \pm 0.2$ at $25^{\circ} \mathrm{C}$, which was close to the literature values for long term aged $\mathrm{La}(\mathrm{OH})_{3}(\mathrm{~s})$ reviewed by $[25,26]$ and to the selected value of $\log K_{\mathrm{s}}^{\circ}=$ $19.72 \pm 0.34$ for $\mathrm{La}(\mathrm{OH})_{3}(\mathrm{~s})$ in [4]. Diakonov et al. [25] calculated the solubility product based on the thermodynamic calculation from the enthalpy and entropy of formation of $\mathrm{La}(\mathrm{OH})_{3}(\mathrm{~s})$. The calculated $\log K_{\mathrm{s}}^{\circ}=20.20$ for $\mathrm{La}(\mathrm{OH})_{3}(\mathrm{~s})$ [25] was approximately one order of magnitude higher than that obtained in the present study. The solubility product for $\mathrm{La}(\mathrm{OH})_{3}\left(\mathrm{cr}, 90{ }^{\circ} \mathrm{C}\right.$ aged $)$ was determined to be $\log K_{\mathrm{s}}^{\circ}=$ $17.1 \pm 0.4$, which was found to be lower by one orders of magnitude than that of $\mathrm{La}(\mathrm{OH})_{3}(\mathrm{cr})$ aged at 25 to $60^{\circ} \mathrm{C}$. Although no significant difference was observed in the bulk solid phases after aging at $25{ }^{\circ} \mathrm{C}$ and $90{ }^{\circ} \mathrm{C}$ as shown in their XRD pat-

TABLE 2: Solubility products and hydrolysis constants $\left(I=0, T_{\text {meas }}=25\right.$ to $\left.60{ }^{\circ} \mathrm{C}\right)$ for $\mathrm{La}$, Eu, and Tm hydroxides and oxides obtained and used in the present study

\begin{tabular}{cccc}
\hline \multicolumn{4}{c}{$\mathrm{La}(\mathrm{OH})_{3}(\mathrm{cr})$} \\
$T_{\text {age }}$ & $T_{\text {meas }}$ & $\log K_{\mathrm{s}}^{\circ}$ & $\log { }^{*} \beta_{1}^{\circ \text { a }}$ \\
\hline $25 \sim 60{ }^{\circ} \mathrm{C}$ & $25{ }^{\circ} \mathrm{C}$ & $19.0 \pm 0.2$ & -8.89 \\
$40 \sim 60{ }^{\circ} \mathrm{C}$ & $40{ }^{\circ} \mathrm{C}$ & $18.3 \pm 0.3$ & -8.54 \\
$50 \sim 60{ }^{\circ} \mathrm{C}$ & $50{ }^{\circ} \mathrm{C}$ & $16.7 \pm 0.3$ & -8.34 \\
$60{ }^{\circ} \mathrm{C}$ & $60{ }^{\circ} \mathrm{C}$ & $17.0 \pm 1.1$ & -8.11 \\
\hline \multicolumn{4}{c}{$\mathrm{La}(\mathrm{OH})_{3}(\mathrm{cr}, 90)$} \\
$T_{\text {age }}$ & $T_{\text {meas }}$ & $\log K_{\mathrm{s}}^{\circ}$ & $\log { }^{*} \beta_{1}^{\circ}$ \\
\hline $90{ }^{\circ} \mathrm{C}$ & $25^{\circ} \mathrm{C}$ & $17.1 \pm 0.4$ \\
\hline \multicolumn{4}{c}{-8.89} \\
\hline \multicolumn{4}{c}{$\mathrm{Tm}{ }_{2} \mathrm{O}_{3}(\mathrm{cr})$} \\
$T_{\text {age }}$ & $T_{\text {meas }}$ & $\log K_{\mathrm{s}}^{\circ}$ & $\log { }^{*} \beta_{1}^{\circ}{ }^{\circ}$ \\
\hline $25 \sim 90{ }^{\circ} \mathrm{C}$ & $25{ }^{\circ} \mathrm{C}$ & $16.9 \pm 0.2$ & -7.34 \\
$40 \sim 60{ }^{\circ} \mathrm{C}$ & $40{ }^{\circ} \mathrm{C}$ & $15.5 \pm 0.2$ & -6.78 \\
$50 \sim 60{ }^{\circ} \mathrm{C}$ & $50{ }^{\circ} \mathrm{C}$ & $14.3 \pm 0.2$ & -6.45 \\
$60{ }^{\circ} \mathrm{C}$ & $60{ }^{\circ} \mathrm{C}$ & $14.3 \pm 0.4$ & -6.10 \\
\hline
\end{tabular}

\begin{tabular}{cccc}
\hline \multicolumn{4}{c}{$\mathrm{Eu}_{2} \mathrm{O}_{3}(\mathrm{cr})$} \\
$T_{\text {age }}$ & $T_{\text {meas }}$ & $\log K_{\mathrm{s}}^{\circ}$ & $\log { }^{*} \beta_{1}^{\circ \text { a }}$ \\
\hline $25 \sim 60{ }^{\circ} \mathrm{C}$ & $25^{\circ} \mathrm{C}$ & $18.4 \pm 0.2$ & -7.66 \\
$40 \sim 60{ }^{\circ} \mathrm{C}$ & $40{ }^{\circ} \mathrm{C}$ & $16.4 \pm 0.2$ & -7.18 \\
$50 \sim 60{ }^{\circ} \mathrm{C}$ & $50{ }^{\circ} \mathrm{C}$ & $14.8 \pm 0.4$ & -6.90 \\
$60{ }^{\circ} \mathrm{C}$ & $60{ }^{\circ} \mathrm{C}$ & $15.5 \pm 0.4$ & -6.60 \\
\hline \multicolumn{4}{c}{$\mathrm{Eu}(\mathrm{OH})_{3}(\mathrm{cr})$} \\
$T_{\text {age }}$ & $T_{\text {meas }}$ & $\log K_{\mathrm{s}}^{\circ}$ & $\log ^{*} \beta_{1}^{\circ \text { a }}$ \\
\hline $90^{\circ} \mathrm{C}$ & $25^{\circ} \mathrm{C}$ & $17.2 \pm 0.3$ & -7.66 \\
\hline \multicolumn{4}{c}{}
\end{tabular}

a) The hydrolysis constants for $\mathrm{La}, \mathrm{Eu}$, and $\mathrm{Tm}$ at $25{ }^{\circ} \mathrm{C}$ were taken from [4]. The values at 40 to $60{ }^{\circ} \mathrm{C}$ were calculated from the temperature dependence of the hydrolysis constants observed in [50] using the van't Hoff equation.
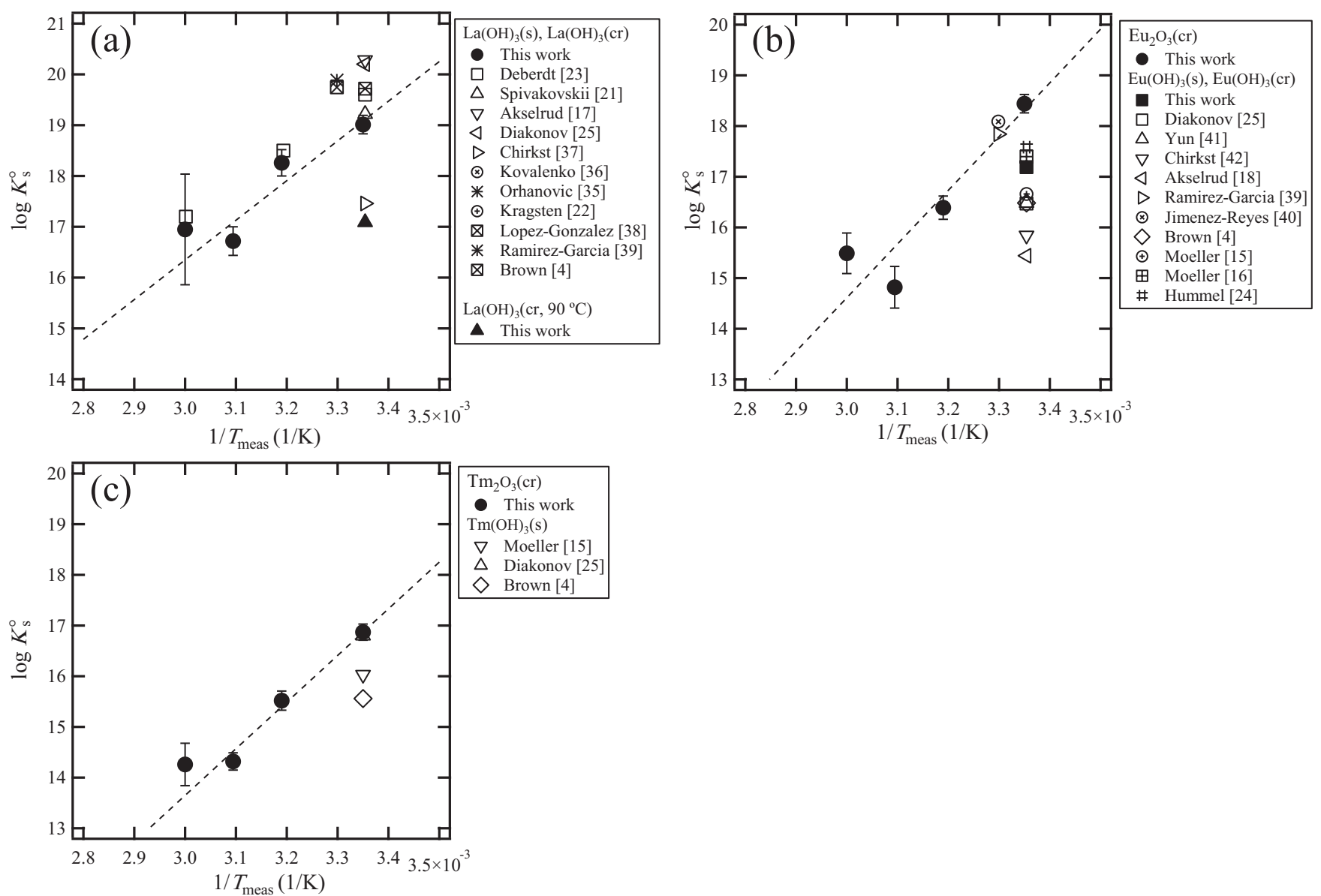

Figure 8. Solubility product values of (a) $\mathrm{La}(\mathrm{OH})_{3}(\mathrm{cr}),(\mathrm{b}) \mathrm{Eu}_{2} \mathrm{O}_{3}(\mathrm{cr}), \mathrm{Eu}(\mathrm{OH})_{3}(\mathrm{cr})$, and (c) $\mathrm{Tm}_{2} \mathrm{O}_{3}(\mathrm{cr})$ as a function of the inverse of measurement temperature. The broken lines in the figures represent the fitted lines in this work based on the integrated van't Hoff equation. 
terns, surface conditions of the solid phases controlling the solubility may be dependent on the aging temperature. Further studies are needed to clarify the effect arising from the bulk and surface condition of the solid phases.

The obtained $\log K_{\mathrm{s}}^{\circ}$ values for $\mathrm{La}(\mathrm{OH})_{3}(\mathrm{cr})$ at $T_{\text {meas }}=25$ to $60{ }^{\circ} \mathrm{C}$ are plotted in Fig. 8(a). The $\log K_{\mathrm{s}}^{\circ}$ value linearly increased with decreasing $T_{\text {meas }}$ and the $\Delta_{\mathrm{r}} H_{\mathrm{m}}\left(\mathrm{La}(\mathrm{OH})_{3}(\mathrm{cr})\right)$ was determined to be $-149.5 \pm 22.5 \mathrm{~kJ} / \mathrm{mol}$ from the obtained slope based on the integrated van't Hoff equation of Eq. (10). A few literature studies investigated the solubility of $\mathrm{La}(\mathrm{OH})_{3}(\mathrm{~s})$ at different $T_{\text {meas }}$ from $25^{\circ} \mathrm{C}[23,38,39]$. Deberdt et al. [23] measured the solubility of $\mathrm{La}(\mathrm{OH})_{3}(\mathrm{~s})$ at $40,60,90$, and $150{ }^{\circ} \mathrm{C}$ as shown in Fig. 7 and determined the $\log K_{\mathrm{s}}^{\circ}$ values at respective temperatures. The $\log K_{\mathrm{s}}^{\circ}$ values at the same $T_{\text {meas }}$ in both studies were found to be in an agreement as shown in Fig. 8(a). A slight difference may arise from a difference in the analysis of the solubility data. The first hydrolysis species, $\mathrm{LaOH}^{2+}$, was taken into consideration in the present study, while the species was not included in the analysis in [23]. The slope of $\log K_{\mathrm{s}}^{\circ}$ against the $1 / T_{\text {meas }}$, and reported $\Delta_{\mathrm{r}} H_{\mathrm{m}}\left(\mathrm{La}(\mathrm{OH})_{3}(\mathrm{cr})\right)=-134.570$ $\mathrm{kJ} / \mathrm{mol}$ [23] matched to those obtained in the present study within the measurement error. It is note that the $\Delta_{\mathrm{r}} H_{\mathrm{m}}\left(\mathrm{Ln}(\mathrm{OH})_{3}(\mathrm{cr})\right)$ values for several lanthanide elements were determined by solution calorimetry $[53,54]$. The $\Delta_{\mathrm{r}} H_{\mathrm{m}}\left(\mathrm{La}(\mathrm{OH})_{3}(\mathrm{cr})\right)=-150.2 \mathrm{~kJ} / \mathrm{mol}$ [53] also agreed well with the obtained value in the present study. These results clearly indicate that the initial $\mathrm{La}_{2} \mathrm{O}_{3}(\mathrm{cr})$ transformed to $\mathrm{La}(\mathrm{OH})_{3}(\mathrm{cr})$ at $25^{\circ} \mathrm{C}$, and control the La solubility as the solubility-limiting solid phase.

For Eu, as suggested by the XRD patterns and the solubility data, the solid phase after aging at 25 to $60{ }^{\circ} \mathrm{C}$ was considered to be $\mathrm{Eu}_{2} \mathrm{O}_{3}$ (cr), while the solid phase after aging at $90{ }^{\circ} \mathrm{C}$ was $\mathrm{Eu}(\mathrm{OH})_{3}(\mathrm{cr})$. The solubility products at $T_{\text {meas }}=25{ }^{\circ} \mathrm{C}$ were determined to be $\log K_{\mathrm{s}}^{\circ}=18.4 \pm 0.2$ for $\mathrm{Eu}_{2} \mathrm{O}_{3}(\mathrm{cr})$, and $\log K_{\mathrm{s}}^{\circ}=$ $17.2 \pm 0.3$ for $\mathrm{Eu}(\mathrm{OH})_{3}(\mathrm{cr})$. In literatures, a number of $\log K_{\mathrm{s}}^{\circ}$ for $\mathrm{Eu}(\mathrm{OH})_{3}(\mathrm{cr})$ has been reported $[15,16,18,25,39-42]$, while no $\log K_{\mathrm{s}}^{\circ}$ value for $\mathrm{Eu}_{2} \mathrm{O}_{3}(\mathrm{cr})$. The obtained $\log K_{\mathrm{s}}^{\circ}$ for $\mathrm{Eu}(\mathrm{OH})_{3}(\mathrm{cr})$ in the present study was slightly higher than the reported values and the selected one of $\log K_{\mathrm{s}}^{\circ}=16.48 \pm 0.30$ in [4].

In Fig. 8(b), the obtained $\log K_{\mathrm{s}}$ values for $\mathrm{Eu}_{2} \mathrm{O}_{3}(\mathrm{cr})$ at $T_{\text {meas }}$ $=25$ to $60{ }^{\circ} \mathrm{C}$ are plotted as a function the inverse of $T_{\text {meas }}$. The $\log K_{\mathrm{s}}$ value increased with decreasing $T_{\text {meas }}$ and the $\Delta_{\mathrm{r}} H_{\mathrm{m}}\left(\mathrm{Eu}_{2} \mathrm{O}_{3}(\mathrm{cr})\right)$ was determined to be $-202.8 \pm 20.1 \mathrm{~kJ} / \mathrm{mol}$ from the its slope. The $\Delta_{\mathrm{r}} H_{\mathrm{m}}\left(\mathrm{Eu}_{2} \mathrm{O}_{3}(\mathrm{cr})\right)$ and $\Delta_{\mathrm{r}} H_{\mathrm{m}}\left(\mathrm{Eu}(\mathrm{OH})_{3}(\mathrm{cr})\right)$ has been reported to be $-209.145 \mathrm{~kJ} / \mathrm{mol}$ and $-143.99 \mathrm{~kJ} / \mathrm{mol}$ determined by solution calorimetry of respective solid phases as summarized in $[4,25,29]$. Although the obtained $\Delta_{\mathrm{r}} H_{\mathrm{m}}\left(\mathrm{Eu}_{2} \mathrm{O}_{3}(\mathrm{cr})\right)$ in the present study much relied on the $\log K_{\mathrm{s}}^{\circ}$ value at each $T_{\text {meas }}$, it is interesting that the obtained value was closer to that reported value for $\mathrm{Eu}_{2} \mathrm{O}_{3}$ (cr). This may suggest that $\mathrm{Eu}_{2} \mathrm{O}_{3}(\mathrm{cr})$ remained stable at $25^{\circ} \mathrm{C}$, and control the Eu solubility as the solubility-limiting solid phase, in contrast to the case of La.

For $\mathrm{Tm}$, the solid phase was considered to be $\mathrm{Tm}_{2} \mathrm{O}_{3}(\mathrm{cr})$, regardless of the aging temperature up to $90{ }^{\circ} \mathrm{C}$. The solubility product at $T_{\text {meas }}=25{ }^{\circ} \mathrm{C}$ was determined to be $\log K_{\mathrm{s}}^{\circ}=$ $16.9 \pm 0.2$. In literatures, only Moeller et al. performed the Tm solubility experiment and reported the solubility product of $\log$ $K_{\mathrm{s}}^{\circ}=16.0[15]$ for fresh $\operatorname{Tm}(\mathrm{OH})_{3}(\mathrm{~s})$ solid phase. The $\log K_{\mathrm{s}}^{\circ}=$ 16.8 was calculated from the $\Delta_{\mathrm{f}} H_{\mathrm{m}}^{\circ}$ and $S_{\mathrm{m}}^{\circ}$ for $\operatorname{Tm}(\mathrm{OH})_{3}(\mathrm{~s})[25$, 26] was rather close to the value obtained in the present study for $\mathrm{Tm}_{2} \mathrm{O}_{3}$ (cr). In Fig. 8(c), the obtained $\log K_{\mathrm{s}}$ values for $\mathrm{Tm}_{2} \mathrm{O}_{3}$ (cr) at $T_{\text {meas }}=25$ to $60{ }^{\circ} \mathrm{C}$ are plotted as a function the inverse of $T_{\text {meas. }}$. The $\Delta_{\mathrm{r}} H_{\mathrm{m}}\left(\mathrm{Tm}_{2} \mathrm{O}_{3}(\mathrm{cr})\right)$ was determined to be $-176.2 \pm 15.7 \mathrm{~kJ} / \mathrm{mol}$ from the slope using Eq. (10). The $\Delta_{\mathrm{r}} H_{\mathrm{m}}\left(\mathrm{Tm}_{2} \mathrm{O}_{3}(\mathrm{cr})\right)$ and $\Delta_{\mathrm{r}} H_{\mathrm{m}}\left(\mathrm{Tm}(\mathrm{OH})_{3}(\mathrm{cr})\right)$ has been reported to be $-189.295 \mathrm{~kJ} / \mathrm{mol}$ and $-141.59 \mathrm{~kJ} / \mathrm{mol}$ determined by solution calorimetry of respective solid phases $[4,25,29]$. Similarly to the case of $\mathrm{Eu}$, the obtained $\Delta_{\mathrm{r}} H_{\mathrm{m}}\left(\mathrm{Tm}_{2} \mathrm{O}_{3}(\mathrm{cr})\right)$ value was also in agreement with the reported value for $\mathrm{Tm}_{2} \mathrm{O}_{3}$ (cr), suggesting that $\mathrm{Tm}_{2} \mathrm{O}_{3}(\mathrm{cr})$ remained stable at $25{ }^{\circ} \mathrm{C}$ to control the Tm solubility as the solubility-limiting solid phase.

\section{Conclusion}

Solubility and solubility limiting solid phase of La, Eu and $\mathrm{Tm}$ were investigated in the solutions of $\mathrm{pH}_{\mathrm{c}} 6$ to 12 after aging at $T_{\text {age }}=25$ to $90{ }^{\circ} \mathrm{C}$. Then, the $\mathrm{La}, \mathrm{Eu}$, and Tm solubilities were measured at $T_{\text {meas }}=25$ to $60{ }^{\circ} \mathrm{C}$ to examine the temperature dependence of the solubility products $\left(K_{\mathrm{s}}^{\circ}\right)$. The XRD patterns, the solubility values, and subsequently obtained the enthalpy of the reaction from the temperature dependence of $\log K_{\mathrm{s}}^{\circ}$ suggested that $\mathrm{La}_{2} \mathrm{O}_{3}(\mathrm{cr})$ transformed to $\mathrm{La}(\mathrm{OH})_{3}(\mathrm{cr})$ to control the La solubility. In the case of $\mathrm{Eu}$, on the other hand, the XRD patterns showed that $\mathrm{Eu}_{2} \mathrm{O}_{3}$ (cr) transformed to $\mathrm{Eu}(\mathrm{OH})_{3}(\mathrm{cr})$ only after the aging at $90{ }^{\circ} \mathrm{C}$, whereas no solid phase transformation was observed at $25{ }^{\circ} \mathrm{C}$. The solubility values and the enthalpy of the reaction suggested that $\mathrm{Eu}_{2} \mathrm{O}_{3}$ (cr) remained stable at $25^{\circ} \mathrm{C}$ to control the Eu solubility. For Tm, the XRD patterns, solubility values and the enthalpy of the reaction indicated that the $\mathrm{Tm}_{2} \mathrm{O}_{3}$ (cr) was stable up to $T_{\text {age }}=90^{\circ} \mathrm{C}$. From lighter to heavier lanthanides (Ln), the oxides of $\mathrm{Ln}_{2} \mathrm{O}_{3}$ (cr) was considered to become more stable comparing to the hydroxides of $\mathrm{Ln}(\mathrm{OH})_{3}(\mathrm{cr})$ and play as the solubility-limiting solid phase in the Ln-OH aqueous systems. It is note that the present study focused on the steady state of the solubility reaction after aging at certain temperatures and periods and revealed the solubility-limiting solid phase and their thermodynamic data. The reaction kinetics of solid phase transformation needs further investigations.

\section{Acknowledgement}

This work was supported in part by the Ministry of Education, Culture, Sports, Science and Technology, Japan (Grant-in-Aid for 16H02447).

\section{References}

(1) Th. Fanghänel, V. Neck, Aquatic chemistry and solubility phenomena of actinide oxides/hydroxides, Pure Appl. Chem., 74 (2002) 1895-1907.

(2) R. Guillaumont, Th. Fanghänel, J. Fuger, I. Grenthe, V. Neck, D. Palmer, M. Rand, Update on the chemical thermodynamics of Uranium, Neptunium, Plutonium, Americium and Technetium. In: Chemical Thermodynamics. Vol. 5, Elsevier, North-Holland, Amsterdam (2003).

(3) M. Rand, J. Fuger, I. Grenthe, V. Neck, D. Rai, Chemical Thermodynamics of Thorium. In: Chemical Thermodynamics. Vol. 11, Elsevier, North-Holland, Amsterdam (2009).

(4) P. Brown, C. Ekberg. Hydrolysis of Metal Ions. Wiley$\mathrm{VCH}$ (2016).

(5) D. Rai, D. A. Moore, C. S. Oakes, M. Yui, Thermodynamic model for the solubility of thorium dioxide in the $\mathrm{Na}^{+}-\mathrm{Cl}^{-}$$\mathrm{OH}^{-}-\mathrm{H}_{2} \mathrm{O}$ system at $23{ }^{\circ} \mathrm{C}$ and $90{ }^{\circ} \mathrm{C}$, Radiochim. Acta 88 (2000) 297-306.

(6) T. Kobayashi, T. Sasaki, I. Takagi, H. Moriyama, Effect of solid phase transformation on the solubility product of thorium hydrous oxide at $363 \mathrm{~K}$, J. Nucl. Sci. Technol., 53 (2016) 1787-1793.

(7) C. H. Delegard, Effects of aging on $\mathrm{PuO}_{2} \cdot x \mathrm{H}_{2} \mathrm{O}$ particle size in alkaline solution, Radiochim. Acta, 101 (2013) 313-322.

(8) D. Rai, R. G. Strickert, D. A. Moore, J. L. Ryan, Am(III) hydrolysis constants and solubility of Am(III) hydroxide, Radiochim.Acta, 33 (1983) 201-206. 
(9) N. M. Edelstein, J. J. Bucher, R. J. Silva, H. Nitsche, Thermodynamic properties of chemical species in nuclear waste, Lawrence Berkeley Laboratory, Report ONWI-399 and LBL-14325 (1983).

(10) H. Nitsche, N. M. Edelstein, Solubility and speciation of actinide ions in near-neutral solutions, Lawrence Berkeley Laboratory, Report LBL-18900 (1985).

(11) W. Runde, J. I. Kim, Chemical behaviour of trivalent and pentavalent americium in saline $\mathrm{NaCl}$-solutions. Studies of transferability of laboratory data to natural conditions, Technische Universität München, Report RCM 01094 (1994).

(12) R. J. Silva, G. Bidoglio, M. H. Rand, P. B. Robouch, Hans Wanner, I. Puigdomenech, Chemical Thermodynamics of Americium. In: Chemical Thermodynamics. Vol. 2, Elsevier, North-Holland, Amsterdam (1995).

(13) R. J. Silva, The solubilities of crystalline neodymium and americium trihydroxides, Lawrence Berkeley Laboratory, Report LBL-15055 (1982).

(14) S. Stadler, J. I. Kim, Hydrolysis reactions of Am(III) and Am(V), Radiochim. Acta, 44/45 (1988) 39-44.

(15) T. Moeller, H. E. Kremers, Observations on the rare earths. An Electrometric Study of the Precipitation of Trivalent Hydrous Rare Earth Oxides or Hydroxides, J. Am. Chem. Soc., 48 (1944) 395-406.

(16) T. Moeller, N. Fogel, Observations on the rare earths: LXI. Precipitation of hydrous oxides or hydroxides from perchlorate solutions. J. Am. Chem. Soc., 73, (1951) 4481.

(17) N. V.Akselrud, V. B.Spivakovskii, Hydroxides and Basic Chlorides of Yttrium and Lanthanum, Russ. J. Inorg. Chem., 5 (1960) 158-163.

(18) N.V. Akselrud, V.I. Ermolenko, Hydroxides and basic chlorides of europium, terbium and holmium. Russ. J. Inorg. Chem., 6 (1961) 397-399.

(19) N. V. Akselrud, Hydroxychlorides and hydroxides of the elements scandium and lanthanides. Uspehi Khimii, 32 (1963) 800-822.

(20) L.I. Buchenko, P.N. Kovalenko, E.M. Tsygankov, M.M. Evstifeev, Determination of the precipitation $\mathrm{pH}$ and the activity products of praseodymium, Russ. J. Inorg. Chem., 15 (1970) 187-189.

(21) V. B. Spivakovskii, G. V. Makovskaya, L. P Moisa, Representation of the Precipitation Conditions of Metals as Their Basic Salts and Hydroxides by pH-Isolines, Russ. J. Inorg. Chem., 22 (1977) 643-644.

(22) J. Kragsten, L. G. Decnop-Weever, Hydroxide complexes of lanthanides-VIII Lanthanum(III) in perchlorate medium, Talanta, 34, (1987) 861-864.

(23) S. Deberdt, S. Castet, J. L. Dandurand, J. C. Harrichoury, I. Louiset, Experimental study of $\mathrm{La}(\mathrm{OH})_{3}$ and $\mathrm{Gd}(\mathrm{OH})_{3}$ solubilities $\left(25\right.$ to $150{ }^{\circ} \mathrm{C}$ ), and La-acetate complexing (25 to $80^{\circ} \mathrm{C}$ ), Chem. Geol., 151 (1998) 349-372.

(24) W. Hummel, U. Berner, E. Curti, F. J. Pearson, T. Thenen, Nagra/PSI Chemical Thermodynamic Data Base 01/01, Radiochim. Acta, 90 (2002) 805-813.

(25) I. I. Diakonov, B. R. Tagirov and K. V. Ragnarsdottir, Standard Thermodynamic Properties and Heat Capadty Equations for Rare Earth Element Hydroxides, Radiochim. Acta, 81, (1998) 107-116.

(26) I.I. Diakonov, K.V. Ragnarsdottir, B.R. Tagirov, Standard thermodynamic properties and heat capacity equations of rare earth hydroxides: II. Ce(III)-, Pr-, Sm-, Eu(III)-, Gd-, Tb-, Dy-, Ho-, Er-, Tm-, Yb-, and Y-hydroxides. Comparison of thermochemical and solubility data, Chem. Geol., 151 (1998) 327-347.

(27) S. A. Wood, The aqueous geochemistry of the rare-earth elements and yttrium 1. Review of available low-temperature data for inorganic complexes and the inorganic REE speciation of natural waters, Chem. Geol., 82 (1990) 159-
186.

(28) S. A. Wood, The aqueous geochemistry of the rare-earth elements and yttrium 2. Theoretical predictions of speciation in hydrothermal solutions to $350^{\circ} \mathrm{C}$ at saturation water vapor pressure, Chem. Geol., 88 (1990) 99-125.

(29) R. J. M. Konings, O. Beneš, A. Kovács, D. Manara, D. Sedmidubský, L. Gorokhov, V. S. Iorish, V. Yungman, E. Shenyavskaya, and E. Osina, The Thermodynamic Properties of the f-Elements and their Compounds. Part 2. The Lanthanide and Actinide Oxides, J. Phys. Chem. Ref. Data, 43 (2014) 013101-01-013101-95.

(30) J. M. Haschke, L. Eyring, Hydrothermal Equilibra and Crystal Growth of Rare Earth Oxides, Hydroxides, Hydroxynitrates, and Hydroxycarbonates, Inorg. Chem., 10 (1971) 2267-2274.

(31) S. Mroczkowski, J. Eckert, H. Meissner, J. C. Doran, Hydrothermal Growth of Single Crystals of Rare Earth Hydroxides, J. Cryst. Growth, 7 (1970) 333-342.

(32) V. Neck, M. Altmaier, Th. Rabung, J. Lützenkirchen, Th. Fanghänel, Thermodynamics of trivalent actinides and neodymium in $\mathrm{NaCl}, \mathrm{MgCl}_{2}$, and $\mathrm{CaCl}_{2}$ solutions: Solubility, hydrolysis, and ternary Ca-M(III)-OH complexes, Pure Appl. Chem., 81 (2009) 1555-1568.

(33) T. Kobayashi, T. Uemura, T. Sasaki, I. Takagi, H. Moriyama, The Solubilities and Solubility Products of Zirconium Hydroxide and Oxide after Aging at 278, 313, and 333 K, Radiochim. Acta, 104 (2016) 183-193.

(34) S. Nishikawa, T. Kobayashi, T. Sasaki, I. Takagi, Solubilities and solubility products of thorium hydroxide under moderate temperature conditions, Radiochim. Acta, 106 (2018) 655-667.

(35)Z. Orhanovic, B. Pokric, H. Füredi, M. Branica, Precipitation and hydrolysis of metallic ions. III. Studies on the solubility of yttrium and some rare earth hydroxides, Croat. Chim. Acta, 38 (1966) 269-276.

(36) P. N. Kovalenko, K. N. Bagdasarov, Concerning the solubility product of lanthanum hydroxide, Zh. Neorg., Khim., 9 (1964) 534-537.

(37)D. E. Chirkst, O. L. Lobacheva, N. V. Dzhevaga, Thermodynamic Properties of Lanthanum(III) and Holmium(III) Hydroxo Compounds, Russ. J. Phys. Chem. A, 85 (2011) 1872-1875.

(38) H. López-González, M. Solache-Ríos, M. Jiménez-Reyes, J. J. Ramírez-García, A. Rojas-Hernández, Effect of Chloride Ions on the Hydrolysis of Trivalent Lanthanum, Praseodymium and Lutetium in Aqueous Solutions of $2 \mathrm{M}$ Ionic Strength, J. Solution Chem., 34 (2005) 427-441.

(39) J. J. Ramírez-García, M. Solache-Ríos, M. Jiménez-Reyes, A. Rojas-Hernández, Solubility and Hydrolysis of La, Pr, $\mathrm{Eu}, \mathrm{Er}$, and $\mathrm{Lu}$ in $1 \mathrm{M} \mathrm{NaCl}$ Ionic Strength at $303 \mathrm{~K}, \mathrm{~J}$. Solution Chem., 32 (2003) 879-896.

(40) M. Jiménez-Reyes, M. Solache-Ríos, A. RojasHernández, Application of the Specific Ion Interaction Theory to the Solubility Product and First Hydrolysis Constant of Europium, J. Solution Chem., 35 (2006) 201214.

(41) J. I. Yun, T. Bundschuh, V. Neck, J.1 Kim, Selective Determination of Europium(III) Oxide and Hydroxide Colloids in Aqueous Solution by Laser-Induced Breakdown Spectroscopy, Appl. Spectrosc., 55 (2001) 273-278.

(42) D. E. Chirkst, O. L. Lobacheva, I. V. Berlinski, Gibbs energies of formation of hydroxides of lanthanides and yttrium, Zh. Fiz., Khim., 84 (2010) 2241-2244.

(43) U.K. Frolova, V. N. Kumok, V. V. Serebrennikov, Hydrolysis of ions of the rare earth elements and yttrium in aqueous solutions, Izv. Vys. Ucheb. Zaved. Khim., 9 (1966) 176-179.

(44) L. N. Usherenko, N. A. Skoril, Ion Hydrolysis of Rare- 
earth Elements, Yttrium, Scandium and thorium in Water and Water-Ethanol Mixtures, Zh. Neorg. Khim., 17 (1972) 2918-2921.

(45) T. Amaya, H. Kakihana, M. Maeda, The Hydrolysis of $\mathrm{Y}^{3+}$, $\mathrm{La}^{3+}, \mathrm{Gd}^{3+}$, and $\mathrm{Er}^{3+}$ Ions in an Aqueous Solution Containing $3 \mathrm{M}(\mathrm{Li}) \mathrm{ClO}_{4}$ as an Ionic Medium. Bull. Soc. Chem. Jpn., 46 (1973) 1720-1723.

(46) K.A. Burkov, E.A. Bus'ko, I.V. Pichugina, Studies of speciation of lanthanum, praseodymium, ytterbium ions in aqueous solutions. Zh. Neorg. Khim., 27 (1982) 643-647.

(47) L. Ciavatta, M. Iuliano, R. Porto, The hydrolysis of the $\mathrm{La}$ (III) ion in aqueous perchlorate solution at $60{ }^{\circ} \mathrm{C}$, Polyhedron, 6 (1987) 1283-1290.

(48) Q. H. Luo, M. C. Shen, X. L. Bao, Y. Ding, A. B. Dai, A study on hydrolytic polymerization of lanthanide ions, Chin. J. Chem., 5 (1990) 412-422.

(49) L. Ciavatta, M. Iuliano, R. Porto, Temperature effect of the speciation of samarium(III) hydrolytic complexes, Ann. Chim., 89 (1999) 881-890.

(50) G. D. Klungness, R. H. Byrne, Comparative hydrolysis behavior of the rare earths and yttrium: the influence of temperature and ionic strength, Polyhedron, 19 (2000) 99-107.

(51) Yu. Ya. Yakubovich, V. G. Alekseev, Hydrolysis Constants of Tervalent Lanthanum and Lanthanide Ions in $0.1 \mathrm{M}$ $\mathrm{KNO}_{3}$ Solution, Russ. J. Inorg. Chem., 57 (2012) 911-915.

(52)D. E. Chirkst, O. L. Lobacheva, I. V. Berlinskii, M. I. Sulimova, The Thermodynamic Properties of Hydroxo Compounds and the Mechanism of Ion Flotation for Cerium, Europium, and Yttrium, Russ. J. Phys. Chem. A, 83 (2009) 2022-2027.

(53) L. Merli, B. Lambert, J. Fuger, Thermochemistry of lanthanum, neodymium, samarium and americium trihydroxides and their relation to the corresponding hydroxycarbonates, J. Nucl Mater., 247 (1997) 172-176.

(54) L. Merli, F. Rorif, J. Fuger, The Enthalpies of Solution of Lanthanide Metals in Hydrochloric Acid at Various Concentrations. Relevance to Nuclear Waste Long Term Storage, Radiochim. Acta, 82 (1998) 3-9. 